\title{
Particle number size distribution and new particle formation under the influence of biomass burning at a high altitude background site at Mt. Yulong (3410 m), China
}

\author{
Dongjie Shang ${ }^{1}$, Min $\mathrm{Hu}^{1,2}$, Jing Zheng ${ }^{1}$, Yanhong Qin ${ }^{1}$, Zhuofei Du ${ }^{1}$, Mengren $\mathbf{L i}^{1}$, Jingyao Fang ${ }^{1}$, Jianfei Peng ${ }^{1}$, \\ Yusheng $\mathrm{Wu}^{1}$, Sihua $\mathrm{Lu}^{1}$, and Song Guo ${ }^{1}$ \\ ${ }^{1}$ State Key Joint Laboratory of Environmental Simulation and Pollution Control, College of Environmental Sciences \\ and Engineering, Peking University, Beijing, 100871, China \\ ${ }^{2}$ Beijing Innovation Center for Engineering Sciences and Advanced Technology, \\ Peking University, 100871, Beijing, China
}

Correspondence: Min Hu (minhu@pku.edu.cn) and Song Guo (songguo@pku.edu.cn)

Received: 23 March 2018 - Discussion started: 3 April 2018

Revised: 23 July 2018 - Accepted: 12 September 2018 - Published: 1 November 2018

\begin{abstract}
Biomass burning (BB) activities have a great impact on the particle number size distribution (PNSD) in the upper troposphere of the Tibetan Plateau, which could affect regional and global climate. An intensive campaign focused on the measurement of the PNSD, gaseous pollutants, and meteorological parameters was conducted at Mt. Yulong, a high-altitude site ( $3410 \mathrm{~m}$ a.s.l.) on the southeastern Tibetan Plateau during the pre-monsoon season (22 March to 15 April). During this period, intensive BB activities in southern Asia were detected by fire maps. The long-range transport of BB pollutants can increase the accumulation mode particles in the background atmosphere at Mt. Yulong. As a consequence, the cloud condensation nuclei $(\mathrm{CCN})$ concentration was found to be $2-8$ times higher during BB periods than during clean periods. Apart from BB, variations of the planet boundary layer (PBL) and new particle formation (NPF) were other factors that influenced the PNSD. However, only three NPF events (with a frequency of $14 \%$ ) were observed at Mt. Yulong. The occurrence of NPF events during clean episodes corresponded to an elevated PBL or transported BB pollutants. Due to the lack of condensable vapors including sulfuric acid and organic compounds, the newly formed particles were not able to grow to $\mathrm{CCN}$ size. Our study emphasizes the influences of $\mathrm{BB}$ on the aerosol and $\mathrm{CCN}$ concentration in the atmosphere of the Tibetan Plateau. These results also have the potential to improve our understanding of the variation of the particle concentration in the
\end{abstract}

upper troposphere, and provide information for regional and global climate models.

\section{Introduction}

Aerosol particles can influence the radiation that reaches the planet's surface by scattering sunlight, and can influence cloud albedo by serving as cloud condensation nuclei (CCN) (IPCC, 2013). The cloud albedo effect of aerosols is one of the biggest uncertainties in global climate models (IPCC, 2013), and depends strongly on the number concentration and size of particles. Numerous studies have concentrated on monitoring the particle number size distribution (PNSD) within the planet boundary layer (PBL), where anthropogenic sources have strong impacts (Peng et al., 2014). However, particles in the pristine free troposphere (FT) have rarely been studied. Particles in the FT mainly originate from the lifting of emission within the PBL by convective, frontal, and orographic lifting (Okamoto and Tanimoto, 2016), or atmospheric nucleation. These particles have a longer lifetime and can be transported longer distances, during which they can exchange with the PBL (Shen et al., 2016; D'Andrea et al., 2016). Hence, studies on the FT are important because (1) CCN in the FT can more directly influence cloud albedo than to surface CCN, and (2) the FT serves as a route for the long-range transport of pollutants. Aircraft studies are a 
direct way to measure FT particles, but they are costly and can only provide data over short time periods. Therefore, measurement studies at high mountain sites are a common method used to study FT particles and analyze the influences of pollution transport on the FT (Shen et al., 2016).

Particles originating from BB in southern Asia can have impacts on the vast atmosphere of the Tibetan Plateau via transport in the FT. As the highest plateau in the world, the Tibetan Plateau has very few anthropogenic sources, and could potentially be used as the continent background. However, recent studies have revealed that smoke plumes from southern Asia can ascend to the FT, and be transported to the Himalayas and the mountain valley of the Tibetan Plateau during the pre-monsoon season (Cong et al., 2015; Lüthi et al., 2015; Bukowiecki et al., 2016). During the pre-monsoon season, the enhanced convection and steep pressure gradient across the Himalaya-Indo-Gangetic region can lift BB particles to higher altitudes (Gautam et al., 2009; Adak, 2014). The particles can then be transported by dry westerly winds, and have impacts on aerosols in the Tibetan Plateau region (Bonasoni et al., 2010; Chen et al., 2014). Former studies have also verified the influence of southern Asian BB episodes on the Tibetan Plateau via the chemical analysis of $\mathrm{K}^{+}$, levoglucosan, etc. However, limited information exists regarding variation in the PNSD under the influence of BB. Furthermore, limited studies have been carried out concerning the contribution of $\mathrm{BB}$ to $\mathrm{CCN}$ in the Tibetan Plateau region.

In addition to primary emissions, new particle formation (NPF) is an important source of particles in the FT, but measurements of NPF are limited. According to model results, nucleation in the FT contributes $35 \%$ of CCN globally (Merikanto et al., 2009). Within the boundary layer, frequent NPF could have an impact on air quality via the continuous growth of newly formed particles (Guo et al, 2014). Considering that the level of preexisting particles in the FT is relatively low, this should provide better conditions for the nucleation of nanoparticles. As a result, NPF has been frequently observed in the FT at various locations, including Mt. Tai (1500 m a.s.1.) (Shen et al., 2016), the Mediterranean Sea (1000-300 m a.s.1.) (Rose et al., 2015), Mt. Puy de Dôme (1465 m a.s.l), Mt. Izana (2367 m a.s.l.) (Rodríguez et al., 2009; García et al., 2014), and the Colorado Rocky Mountains (2900 m a.s.l.) (Boy et al., 2008). However, NPF events occur less frequently in the Indian foothills of the Himalayas (2080 m) (Neitola et al., 2011). Studies at mountain sites have considered that the frequency of NPF corresponds to rises in the PBL height, which can raise the concentration of anthropogenic $\mathrm{SO}_{2}, \mathrm{NH}_{3}$, and other nucleation precursors. The mechanisms of the formation and growth of nanoparticles in the FT remain ambiguous (Bianchi et al., 2016), meaning that comprehensive measurements of PNSD as well as trace gases at high mountain sites are necessary to provide information on this topic.
This study aimed to (1) investigate the influence of BB from southern Asia on the PNSD and CCN concentrations in the southeast of the Tibetan Plateau, and (2) characterize NPF at high mountain sites. To accomplish these aims, a comprehensive measurement effort was conducted at a background site at Mt. Yulong (3410 ma.s.l.), during the premonsoon season.

\section{Experiments and data analysis}

\subsection{Monitoring site}

An intensive field campaign was conducted from 22 March to 15 April at a high mountain site at Mt. Yulong $\left(27.2^{\circ} \mathrm{N}\right.$, 100.2 $2^{\circ} \mathrm{E}$ ) in southwestern China, in the southeastern corner of the Tibetan Plateau, at an altitude of $3410 \mathrm{~m}$ a.s.l. This site is one of the national regional background sites coordinated by the Chinese Environmental Monitoring Center (CEMC), and is also a remote site on the transport route of southern Asian pollutants during the pre-monsoon season. At the foot of Mt. Yulong, $36 \mathrm{~km}$ to the south of the site, is the famous "Old Town of Lijiang", a populated tourist location. More details regarding the monitoring site can be found in Zheng et al. (2017).

\subsection{Instrumentation}

PNSD was measured with a time resolution of $5 \mathrm{~min}$, using a set of two scanning mobility particle sizers (SMPS, TSI Inc., St. Paul, MN, USA) and an aerodynamic particle sizer (APS, TSI model 3321, TSI Inc., St. Paul, MN, USA). The first SMPS consisted of a short differential mobility analyzer (DMA, Model 3085) and an ultra-condensing particle counter (UCPC, Model 3776, with a flow rate of $1.5 \mathrm{~L} \mathrm{~min}^{-1}$ ) and was used to measure the 3-60 nm particles. The second SMPS with long DMA (Model 3081) and normal CPC (Model 3022, flow rate $0.3 \mathrm{~L} \mathrm{~min}^{-1}$ ) was used to measure the 60-700 nm particles. A silicon diffusion tube was placed before the SMPS, which kept the relative humidity (RH) of the sampling air under $35 \%$. Diffusion loss and multiple charging calibration of the particles was carried out for SMPS data. The APS, with a flow rate of $1 \mathrm{~L} \mathrm{~min}^{-1}$, was used to measure the $0.5-10 \mu \mathrm{m}$ particles. The results from the APS were modified to Stokes diameter assuming the particle density to be $1.7 \mu \mathrm{g} \mathrm{m}^{-3}$, before they were combined with the SMPS data. A bypass flow was added before the inlet cutoff to meet the working flow rate of the $\mathrm{PM}_{10}$ cyclone $\left(16.7 \mathrm{~L} \mathrm{~min}^{-1}\right)$.

To investigate the influence of $\mathrm{BB}$ on aerosols, a highresolution time-of-flight aerosol mass spectrometer (HRTOF-AMS) was deployed to measure the chemical composition of aerosols. Using this instrument, we can obtain the concentration of nitrate, sulfate, ammonium, chloride, and a high-resolution mass spectrum of organics, especially for the fragments of BB organic markers. Black carbon (BC) is another important marker for combustion sources. In this study, 
$\mathrm{BC}$ was measured using an Aethalometer (Magee Scientific, USA, type AE31); this was carried out by collecting aerosol particles on a filter stripe and analyzing the transmission of seven wavelengths of lights from 370 to $950 \mathrm{~nm}$. The BC concentration was calculated as a multiple of the light absorption coefficient at $880 \mathrm{~nm}$, with the default mass attenuation cross sections of $16.6 \mathrm{~m}^{2} \mathrm{~g}^{-1}$ (Fröhlich et al., 2015). To get the concentration of organic tracers of the new particle formation, an online gas chromatograph coupled with a mass spectrometer and flame ionization detectors (GCMS/FID) was used to measure the non-methane hydrocarbons (NMHCs), including benzene, toluene, monoterpene, etc.

Meteorological parameters, $\mathrm{PM}_{2.5}$, and trace gases were also measured by online instruments during the campaign (Table $\mathrm{S} 1$ in the Supplement). $\mathrm{NO}$ and $\mathrm{NO}_{2}$ measurements were conducted using a commercial instrument (Thermo Scientific "Model 42i NO- $\mathrm{NO}_{2}-\mathrm{NO}_{x}$ Analyzer") that utilized the chemiluminescence technique. $\mathrm{NO}_{2}$ was deoxidized to $\mathrm{NO}$ by a molybdenum catalyzer before detection. The $\mathrm{O}_{3}$ measurement was performed using ultraviolet (UV) absorption by a "Model 49i Ozone Analyzer" (Thermo Scientific). $\mathrm{CO}$ was detected using infrared spectrophotometry (Thermo Scientific model 48i-TLE). $\mathrm{SO}_{2}$ was measured by a commercial instrument (Thermo Scientific model 43i-TLE) using the ultraviolet fluorescence method. Due to the instrument noise and the rather low concentrations of $\mathrm{SO}_{2}$, the relative uncertainties of the $\mathrm{SO}_{2}$ measurement were high for data under $0.05 \mathrm{ppb}$.

\subsection{Data processing}

\subsubsection{Backward trajectory analysis}

The $48 \mathrm{~h}$ backward trajectories of the air mass were computed at $4000 \mathrm{~m}$ a.s.l. (600 $\mathrm{m}$ above the ground at the Mt. Yulong site) by the Weather Research and Forecasting (WRF) model (version 3.61) to identify the impacts from southern Asia. The fire spots were obtained from the Moderate Resolution Imaging Spectroradiometer (MODIS) satellite map (https://firms.modaps.eosdis.nasa.gov/firemap/; last $26 \mathrm{Au}$ gust 2016). In order to characterize the air mass origin during the NPF events, the $48 \mathrm{~h}$ backward trajectories at $600 \mathrm{~m}$ above the ground were calculated using the NOAA HYSPLIT 4 (Hybrid Single-Particle Lagrangian Integrated Trajectory) model (Draxier and Hess, 1998).

\subsubsection{Parameterization of NPF}

The data of each PNSD during NPF were fitted as the sum of two-mode or three-mode lognormal distribution (Hussein et al., 2005), including the geometric mean diameter $D_{\mathrm{m}}$, geometric standard deviation $\sigma_{\mathrm{m}}$, and total number concentration of each mode. During the NPF events, the growth rate (GR) was calculated as the variation of the mean diameter $D_{\mathrm{m}}$ of newly formed mode in unit internal:

$\mathrm{GR}=\frac{\Delta D_{\mathrm{m}}}{\Delta t}$.

The formation rate (FR) was calculated for the nucleation fraction of the particles $(3-25 \mathrm{~nm})$, using the following formula:

$J_{3-25}=\frac{\mathrm{d} N_{3-25}}{\mathrm{~d} t}+N_{3-25} \cdot \mathrm{CoagS}_{8}+F_{\text {growth }}$,

where $N_{3-25}$ is number concentration of particles within the $3-25 \mathrm{~nm}$ size range, and $\mathrm{CoagS}_{8}$ is the coagulation rate of particles with diameter of $8 \mathrm{~nm}$, which is the geometric mean of 3-25 nm. The coagulation rate was calculated as follows:

$\operatorname{CoagS}\left(D_{\mathrm{p}}\right)=\int K\left(D_{\mathrm{p}}, D_{\mathrm{p}}{ }^{\prime}\right) n\left(D_{\mathrm{p}}{ }^{\prime}\right) \mathrm{d} D_{\mathrm{p}}{ }^{\prime}$,

where $n\left(D_{\mathrm{p}}{ }^{\prime}\right)$ is number concentration of particles with a size of $D_{\mathrm{p}}{ }^{\prime}$, and $K\left(D_{\mathrm{p}}, D_{\mathrm{p}}{ }^{\prime}\right)$ is the coagulation coefficient between $D_{\mathrm{p}}$ and $D_{\mathrm{p}}{ }^{\prime}$ particles. During nucleation events, there were a negligible number of particles that grew beyond $25 \mathrm{~nm}$, so the last term in formula of was not included (Dal Maso et al., 2005). To quantify the limitation of NPF from preexisting particles, the condensation sink (CS) was calculated as follows:

$\mathrm{CS}=2 \pi D \sum_{i} \beta \cdot D_{i} \cdot N_{i}$,

where $D$ is the diffusion coefficient of the condensational vapor (e.g., sulfuric acid), $\beta$ is the transitional regime correction factor, and $D_{i}$ and $N_{i}$ are the diameter and number concentration of particles in class $i$, respectively. In the calculation described above, all diameters were dry diameters directly measured from the SMPS instruments, so the coagulation and condensation sinks could be underestimated.

Sulfuric acid was thought to be the most important precursor of NPF events (Sipilä et al., 2010), and could contribute to particle growth by condensation (Yue et al., 2010; Zhang et al., 2012). In this study, the content of $\mathrm{H}_{2} \mathrm{SO}_{4}$ was calculated using a pseudo-steady state method (Kulmala et al., 2001):

$\left[\mathrm{H}_{2} \mathrm{SO}_{4}\right]=k \cdot[\mathrm{OH}]\left[\mathrm{SO}_{2}\right] / \mathrm{CS}$,

where $[\mathrm{OH}]$ and $\left[\mathrm{SO}_{2}\right]$ are the number concentrations of $\mathrm{OH}$ radicals and $\mathrm{SO}_{2}$, respectively, and the value of $k$ is $10^{-12} \mathrm{~cm}^{3} \mathrm{~s}^{-1}$. [OH] was estimated using

$[\mathrm{OH}]=a\left(J \mathrm{O}^{1} \mathrm{D}\right)^{\alpha}\left(J_{\mathrm{NO}_{2}}\right)^{\beta} \frac{b\left[\mathrm{NO}_{2}\right]+1}{c\left[\mathrm{NO}_{2}\right]^{2}+d\left[\mathrm{NO}_{2}\right]+1}$,

where $\alpha=0.83, \beta=0.19, a=4.1 \times 10^{9}, b=140, c=0.41$, and $d=1.7$ (Ehhalt and Rohrer, 2000). The contribution of sulfuric acid condensation to particle growth was calculated following Yue et al. (2010). 


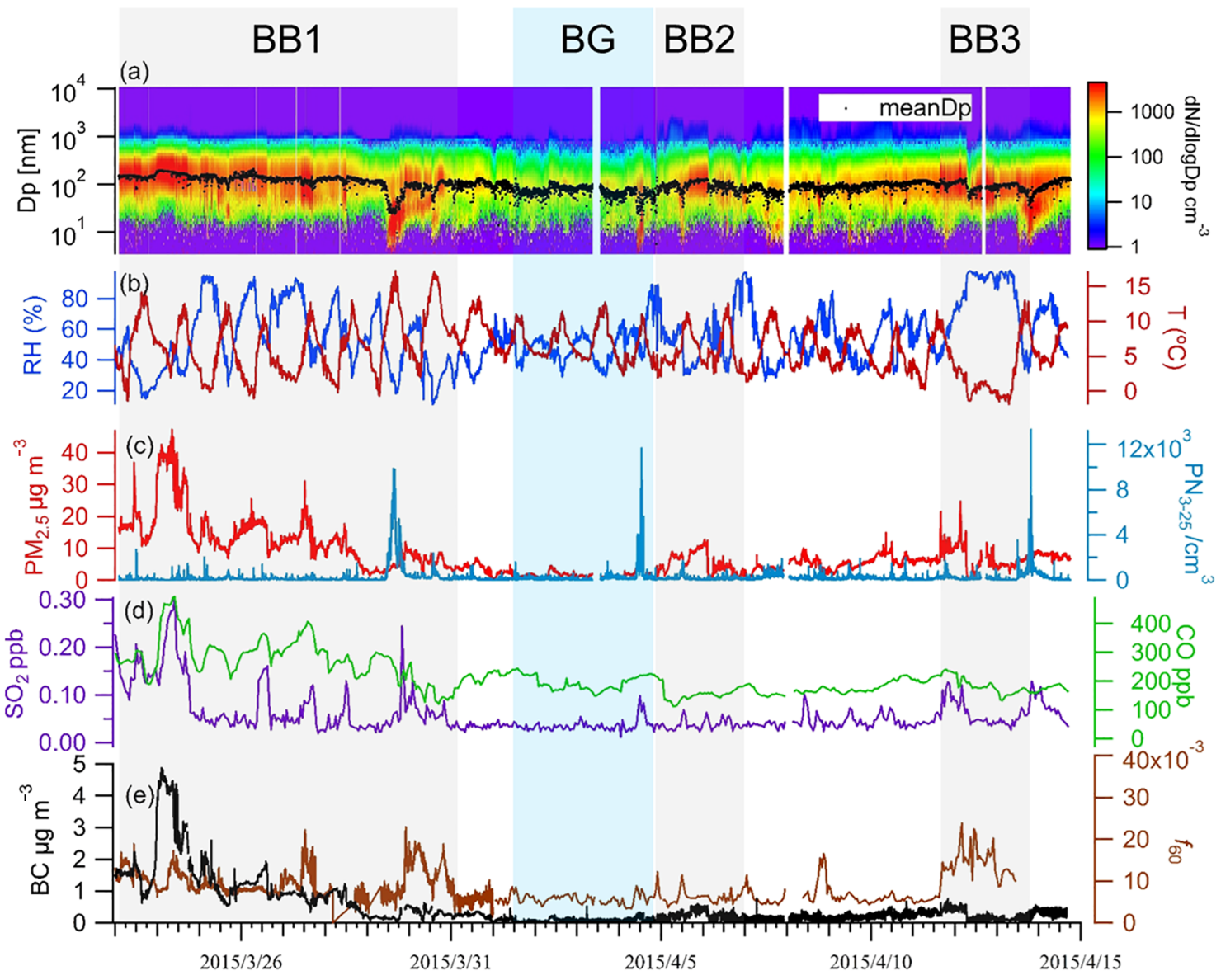

Figure 1. Time series of (a) the particle number size distribution and the geometric mean diameter, (b) the ambient temperature and the relative humidity, (c) the $\mathrm{PM}_{2.5}$ mass concentration and the number concentration of nucleation mode (3-25 nm) particles $\left(\mathrm{PN}_{3-25}\right),(\mathbf{d})$ the $\mathrm{SO}_{2}$ and $\mathrm{CO}$ concentration, and (e) the black carbon concentration and fraction of $f 60$ (organic fragment ions with $m / z=60$ ) during the monitoring campaign. Periods influenced by biomass burning (BB1, BB2, BB3) are marked using grey shades, and the period representing background conditions (BG) is marked using blue shade.

Table 1. Densities and hygroscopic parameters of the compounds used in the CCN calculation.

\begin{tabular}{lrrrrrr}
\hline Species & $\mathrm{NH}_{4} \mathrm{NO}_{3}$ & $\mathrm{NH}_{4} \mathrm{HSO}_{4}$ & $\left(\mathrm{NH}_{4}\right)_{2} \mathrm{SO}_{4}$ & $\mathrm{H}_{2} \mathrm{SO}_{4}$ & Organics & $\mathrm{BC}$ \\
\hline$\rho\left(\mathrm{kg} \mathrm{m}^{-3}\right)$ & 1720 & 1780 & 1769 & 1830 & 1400 & 1700 \\
$\kappa$ & 0.67 & 0.61 & 0.61 & 0.91 & 0.1 & 0
\end{tabular}

\subsubsection{Calculation of $\mathrm{CCN}$ concentration}

In order to evaluate the variation of the indirect climate effects of the particles at Mt. Yulong, the CCN number concentration was estimated from data of PNSD and particle chemical composition. Firstly, SNA (sulfate, nitrate, ammonium) was ion-coupled to establish the exact chemical compounds of the inorganic salts in the particles. $\mathrm{NH}_{4} \mathrm{NO}_{3}, \mathrm{H}_{2} \mathrm{SO}_{4}$, $\mathrm{NH}_{4} \mathrm{HSO}_{4}$, and $\left(\mathrm{NH}_{4}\right)_{2} \mathrm{SO}_{4}$ were calculated using the following formula:

$n_{\mathrm{NH}_{4} \mathrm{NO}_{3}}=n_{\mathrm{NO}_{3}^{-}}$

$$
\begin{aligned}
& n_{\mathrm{H}_{2} \mathrm{SO}_{4}}=\max \left(0, n_{\mathrm{SO}_{4}^{2-}} n_{\mathrm{NH}_{4}^{+}}+n_{\mathrm{NO}_{3}^{-}}\right), \\
& n_{\mathrm{NH}_{4} \mathrm{HSO}_{4}}=\min \left(2 n_{\mathrm{SO}_{4}^{2-}} n_{\mathrm{NH}_{4}^{+}}+n_{\mathrm{NO}_{3}^{-}}, n_{\mathrm{NH}_{4}^{+}} n_{\mathrm{NO}_{3}^{-}}\right), \\
& n_{\left(\mathrm{NH}_{4}\right)_{2} \mathrm{HSO}_{4}}=\max \left(n_{\mathrm{NH}_{4}^{+}} n_{\mathrm{NO}_{3}^{-}} n_{\mathrm{SO}_{4}^{2-}}, 0\right),
\end{aligned}
$$

where $n$ is the mole number of the specific compounds (Gysel et al., 2007). Based on $\kappa$-Köhler theory and the Zdanovskii-Stokes-Robinson (ZSR) mixing rule, the hygroscopic parameter of mixed particles can be calculated as fol- 
lows (Petters and Kreidenweis, 2007):

$\kappa=\sum_{1}^{n} \varepsilon_{m} \kappa_{m}$,

where $\varepsilon_{m}$ is the volume fraction of the composition $m$ in particles, and $\kappa_{m}$ is the hygroscopic parameter of pure composition $m$. In this research, we consider secondary inorganic ions, organics, and $\mathrm{BC}$ as the major components of particles, and enter them into the ZSR mixing formula. The correlated parameters for the compounds we used are given in Table 1.

Based on $\kappa$-Köhler theory, the relationship between $\kappa$ and $D_{\text {c }}$ under certain critical supersaturation $\left(S_{\mathrm{c}}\right)$ is:

$\kappa=\frac{4 A^{3}}{27 D_{c}^{3} \ln ^{2} S_{c}}, \quad A=\frac{4 \sigma_{s / a} M_{\mathrm{W}}}{R T \rho_{\mathrm{W}}}$,

where $\sigma_{\mathrm{s} / \mathrm{a}}$ is the surface tension of water, $M_{\mathrm{W}}$ and $\rho_{\mathrm{W}}$ are the molecular weight and density of water, respectively, $R$ is $8.317 \mathrm{~J} \mathrm{~mol}^{-1} \mathrm{~K}^{-1}$, and $T$ is the ambient temperature. With the $\kappa$ of the particles, the critical diameter $D_{\mathrm{c}}$ of the $\mathrm{CCN}$ activation can be achieved with this formula. Then the number concentration of $\mathrm{CCN}$ can be calculated as the number concentration of particles larger than $D_{\mathrm{c}}$.

\section{Results and discussion}

\subsection{Particle number size distribution}

\subsubsection{Particle and meteorology parameters}

Figure 1 shows the time series of the PNSD and correlated meteorological parameters. The temperature and relative humidity were $6.1 \pm 3.5^{\circ} \mathrm{C}$ and $54.9 \pm 19.7 \%$, respectively (Fig. 1b). Southeasterly winds were dominant during the campaign, followed by southerly and southwesterly winds. The average wind speed was $2.9 \pm 1.8 \mathrm{~m} \mathrm{~s}^{-1}$ (Fig. S1 in the Supplement). Most of the monitoring days were sunny, which favored the nucleation process, while short periods of rainfall occurred on 24 and 26 March and 4, 6, 7, 8, 10, and 11 April. On 12 April there was heavy snow, and the RH was over $90 \%$.

As a background high altitude site on the Tibetan Plateau, the Mt. Yulong site displayed a low particle concentration and strong oxidation capacity. On average $\mathrm{PM}_{2.5}$ was $10.51 \pm 9.16 \mu \mathrm{g} \mathrm{m}^{-3}$, which is similar to the results from the northeastern slope of the Tibetan Plateau (Xu et al., 2014; Du et al., 2015). This result was only $1 / 10-1 / 3$ of that in the atmosphere of respective urban and rural regions in China, indicating a background situation in southwestern China (Zheng et al., 2016). However, the $\mathrm{PM}_{2.5}$ concentration at the Mt. Yulong background site during the monsoon season was around 3 times the concentration observed Qilian Shan Station (4180 ma.s.l.), in the northeast of the Tibetan Plateau (Xu et al., 2015), and at Jungfraujoch (3580 m a.s.1.),
Switzerland (Bukowiecki et al., 2016), both of which have a similar altitude. This indicates relatively stronger anthropogenic influences at Mt. Yulong during this period. From 22 to 30 March, 4 to 5 April, and 11 to 12 April, the particle mass concentration exceeded $10 \mu \mathrm{g} \mathrm{m}^{-3}$, which constituted a pollution episode.

During the measurement period, the ozone level was $50.1 \pm 7.0 \mathrm{ppbv}$, which is similar to the results from high mountain sites in Europe (Cristofanelli et al., 2016; Okamoto and Tanimoto, 2016) and higher than the results from Beijing during spring. This indicates that the atmosphere at the Mt. Yulong site had a higher oxidation capacity for the secondary transformation of pollutants. The concentrations of $\mathrm{NO}_{x}$ and $\mathrm{NO}$ were $0.94 \pm 0.62$ and $0.07 \pm 0.05 \mathrm{ppbv}$, respectively. The $\mathrm{SO}_{2}$ concentration was $0.06 \pm 0.05 \mathrm{ppbv}$, which is around the detection limit, showing no strong primary pollution. The $\mathrm{CO}$ concentration was $0.22 \pm 0.07 \mathrm{ppmv}$, and showed a higher level at the beginning of the campaign ( 24 to $30 \mathrm{March}$ ), which may have been the result of the influence of BB (Fig. 1d).

Although the particles we measured in this study had a larger size range than most other studies, the results are still comparable, considering that Aitken and accumulation mode particles, which all measurements included, constitute most of the particle number concentration (PN). Table 2 shows the particle number concentrations in atmosphere at Mt. Yulong and other high altitude stations. The total number concentration of $\mathrm{PM}_{10}$ was $1600 \pm 1290 \mathrm{~cm}^{-3}$ during the monsoon season at Mt. Yulong, which is slightly lower than concentrations measured at other sites throughout the Tibetan Plateau, e.g., Waliguan and Mukteshwar, and Mt. Huang. However, this result is several times higher than those from areas with scarce emission sources, e.g., the Alps and Antarctica. Conversely, the PN did not show a clear trend as the altitude increased, which means that regional emission and transport had larger impact on aerosols in the upper troposphere than vertical distribution did. We define $N_{3-25}, N_{25-100}$, $N_{100-1000}$, and $N_{1000+}$ as number concentrations of particles with diameters of 3-25, 25-100, 100-1000 nm, and 1$10 \mu \mathrm{m}$, respectively. There were bursts of $N_{3-25}$ on midday on 29 March, 4 April, and 13 April, with the peak values at 9900, 11700 , and $5400 \mathrm{~cm}^{-3}$, respectively (Fig. 1c). During those periods, the geometric mean diameter of the particles was lower than $25 \mathrm{~nm}$. These events may have resulted from local or regional NPF, which is discussed later.

\subsubsection{Analysis of PNSD and PVSD}

The average PNSD during the measurement is shown in Fig. 2a. In this study, we sorted the particles by their sizes (Dal Maso et al., 2005). We consider that $N_{25-100}$ correlates to primary emissions, whilst $N_{100-1000}$ has stronger connection with secondary formation. According to the results from bench tests and road tests, gasoline and diesel vehicles emit particles within the $10-100 \mathrm{~nm}$ range (Harris and 
Table 2. Particle number concentration (PN) of high altitude sites around the world compared with this study.

\begin{tabular}{lrlrrl}
\hline Location & Altitude [m] & Date & Size range [nm] & PN [cm $\left.{ }^{-3}\right]$ & Reference \\
\hline Sierra Nevada Mountains, US & 1315 & May-Nov 2002 & $10-400$ & 4300 & Lunden et al. (2006) \\
Mt. Tai, China & 1534 & Jul 2010-Feb 2012 & $3-2500$ & $11800 \pm 6200$ & Shen et al. (2016) \\
Mt. Huang, China & 1840 & Apr-Aug 2008 & $10-10000$ & 2350 & Zhang et al. (2016) \\
Mukteshwar, India & 2180 & Nov 2005-Nov 2008 & $10-800$ & 2730 & Komppula et al. (2009) \\
Izana Observatory, Spain & 2367 & Nov 2006-Dec 2007 & $3-660$ & $480-4600$ & Rodríguez et al. (2009) \\
Mt. Norikura, Japan & 2770 & Sep 2001, Jul-Sep 2002 & $9-300$ & $260-1600$ & Nishita et al. (2008) \\
University of Colorado Mountain & 2900 & Jul 2006 & $3-800$ & $2881-19947$ & Boy et al. (2008) \\
Research Station, US & & & & & \\
Dome C, Antarctica & 3200 & Spring 2008-2009 & $10-600$ & $17.9-457$ & Järvinen et al. (2013) \\
Storm Peak Laboratory, US & 3210 & Mar 2012 & $10-10000$ & 3100 & Yu and Hallar (2014) \\
Jungfraujoch, Switzerland & 3580 & 1995-2015 & $10-10000$ & 757 & Bukowiecki et al. (2016) \\
Wangliguan, China & 3816 & Sep 2005-May 2007 & $12-570$ & 2030 & Kivekäs et al. (2009) \\
Mt. Daban, China & 3295 & Sep-Oct 2013 & $12-478$ & 2300 & Du et al. (2015) \\
Mt. Yulong, China & 3410 & May-April 2015 & $3-10000$ & $1600 \pm 1290$ & This Study \\
\hline
\end{tabular}
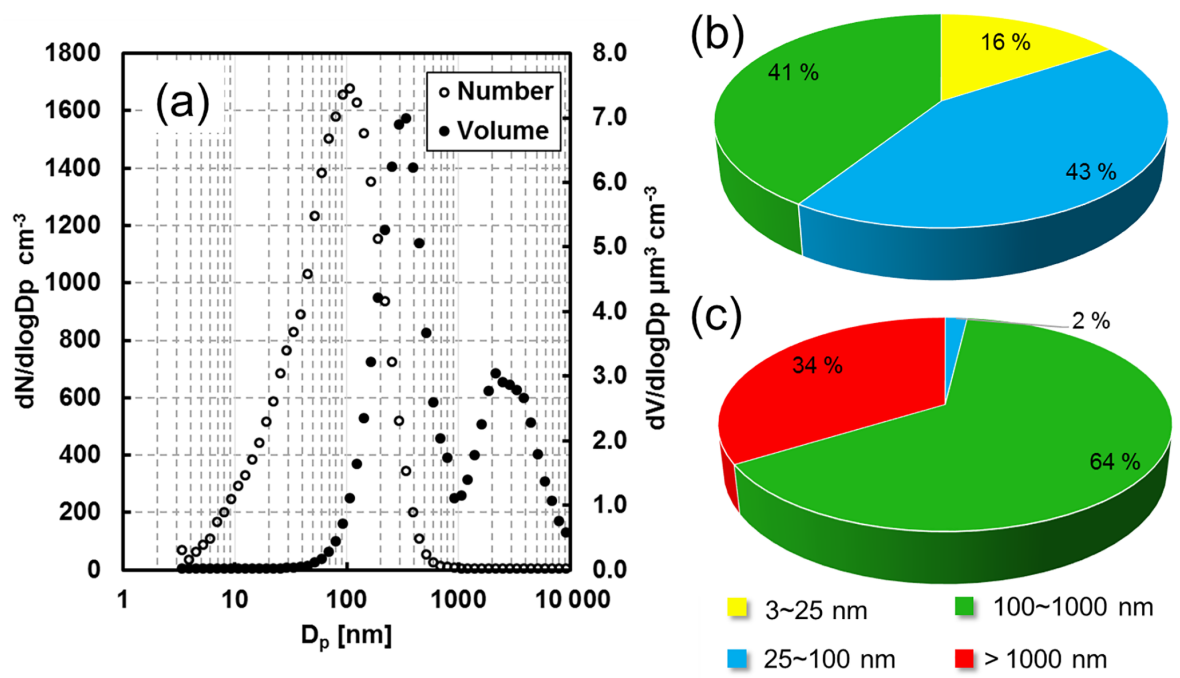

Figure 2. Particle size distribution in the atmosphere at Mt. Yulong. (a) Mean size distribution of the particle number (hollow circle) and volume (filled circle) concentrations; the contribution of different fractions to the total particle (b) number concentration and (c) volume concentration. Different colors represent different size ranges: yellow (3-25 nm), blue $(25-100 \mathrm{~nm})$, green $(100-1000 \mathrm{~nm})$, and red (1$10 \mu \mathrm{m})$.

Maricq, 2001; Kittelson et al., 2006; Benajes et al., 2017; Tan et al., 2017). While studies on source apportionment of the atmospheric PNSD have found that secondary formation or long-range transport mainly contributed particles within the 100-1000 nm range (Wang et al., 2013b; Vu et al., 2015). The diameter with highest particle number concentration in this study $\left(D_{\mathrm{p}-\max }\right)$ was $107 \mathrm{~nm}$. The number concentration $\left(\mathrm{d} N / \mathrm{d} \log D_{m \mathrm{p}}\right)$ was larger than $1000 \mathrm{~cm}^{-3}$ between 40 and $200 \mathrm{~nm}$, which was the area adjacent to $N_{25-100}$ and $N_{100-1000}$. This indicates that both primary emission sources and secondary formation processes were influencing the Mt. Yulong site. $N_{3-25}, N_{25-100}$, and $N_{100-1000}$ were 244,676 , and $638 \mathrm{~cm}^{-3}$, constituting $16 \%, 43 \%$, and $41 \%$ of total concentration, respectively.
In contrast to PNSD, the particle volume (PV) exhibited a bimodal distribution (Fig. 2a). The first peak had an extreme value at $340 \mathrm{~nm}$, which represented the contribution of primary emission and aging processes. This mass peak constituted $66 \%$ of the total PV, including $\mathrm{PV}_{25-100}(2 \%)$ and $\mathrm{PV}_{100-1000}(64 \%)$. The $3-25 \mathrm{~nm}$ particles had a negligible influence on the PV. The other mode in the PV size distribution was within the $1-10 \mu \mathrm{m}$ range, with the $D_{\mathrm{p}-\max }$ at $2.2 \mu \mathrm{m}$. This mode could be attributed to suspended soil. The volume of $1-10 \mu \mathrm{m}$ particles constituted $34 \%$ of the total PV, which was similar to Qilian Shan Station (38\%) in the northeast of the Tibetan Plateau (Xu et al., 2015) but higher than that urban Beijing (25\%) (Wu et al., 2008). This was due to the 
Table 3. Fitted parameters of the lognormal modes for the different periods. $\mu, \sigma$, and $N$ represent the mean diameter, standard deviation, and total number concentration of each mode, respectively. "Total" represents the mean result of all data achieved from the campaign.

\begin{tabular}{lrrr|rrr|rrr}
\hline Period & \multicolumn{3}{c}{$\mu[\mathrm{nm}]$} & \multicolumn{3}{c|}{$\sigma[\mathrm{nm}]$} & \multicolumn{3}{c}{$N\left[\mathrm{~cm}^{-3}\right]$} \\
\cline { 2 - 9 } & Mode 1 & Mode 2 & Mode 3 & Mode 1 & Mode 2 & Mode 3 & Mode 1 & Mode 2 & Mode 3 \\
\hline Total & 16 & 52 & 130 & 1.75 & 1.75 & 1.77 & 221 & 488 & 861 \\
BB1 & 23 & 92 & 169 & 1.94 & 1.91 & 1.63 & 428 & 1014 & 744 \\
BB2 & 16 & 47 & 106 & 1.75 & 1.75 & 1.75 & 117 & 302 & 775 \\
BB3 & 15 & 70 & 130 & 1.75 & 1.75 & 1.72 & 106 & 1309 & 628 \\
BG & 15 & 79 & - & 2.03 & 1.73 & - & 301 & 368 & - \\
\hline
\end{tabular}

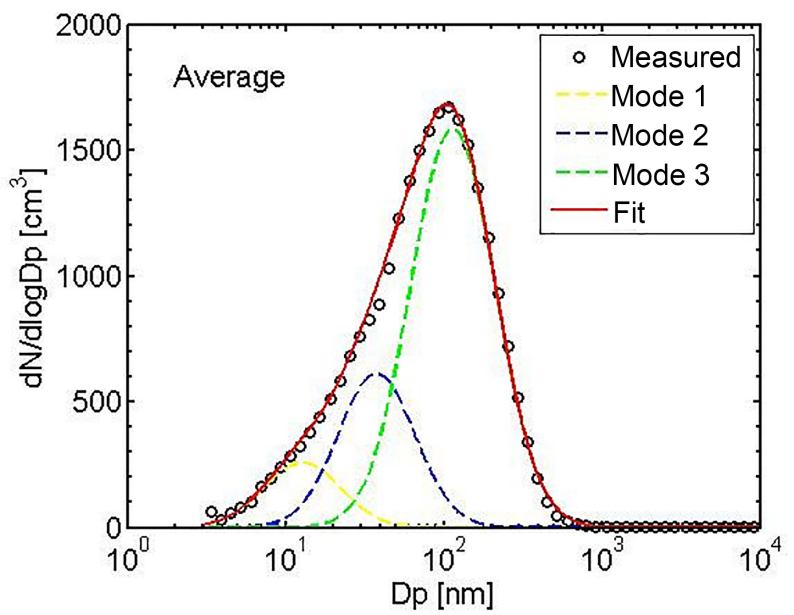

Figure 3. Lognormal fit (three modes) of the average particle number size distribution during the campaign at Mt. Yulong. Black circles mark the measured PNSD, colored dashed lines represent the PNSD of fitting modes, and the red solid line marks the sum of the PNSD of all fitting modes. Mode 1, 2, and 3 are nucleation mode, Aitken mode, and accumulation mode, respectively.

fact that the Mt. Yulong site had significantly fewer emission sources and stronger wind compared to urban Beijing.

To better characterize the contribution from different process, the mean PNSD was fitted to three lognormal modes (Fig. 3, Table 3). We define the three fitted modes as the nucleation mode, the Aitken mode, and the accumulation mode, based on their geometric mean diameters, which were within $3-25,25-100$, and $100-1000 \mathrm{~nm}$, respectively. The nucleation mode can be derived from the nucleation process. Nucleation mode particles contributed $15 \%$ to the total PN, which was half the proportion of nucleation mode particles found at Mt. Tai; this indicates a lower impact from nucleation events at Mt. Yulong. The median diameter of Aitken and accumulation mode particles are 52 and $130 \mathrm{~nm}$, respectively. These mean diameters are similar to results from Jungfraujoch (Bukowiecki et al., 2016) and Beijing (Wu et al., 2008). Accumulation mode particles, which are correlated with secondary formation (mode 3), contributed $54 \%$ of total PN, which is twice as high as the result from ur- ban Beijing (Wu et al., 2008), and similar to the results from the pristine atmosphere of Jungfraujoch (Bukowiecki et al., 2016). This indicates that the aerosols that arrived at Mt. Yulong were aged during transport.

\subsection{Influence of PBL diurnal variation on PNSD}

Figure 4 shows the diurnal variation of $N_{3-25}, N_{25-100}$, and $N_{100-1000}$ during the sampling period. The particle number concentration in the nucleation and Aitken fractions show a clear diurnal variation. The mean value of $N_{3-25}$ started to increase at 10:00 (please note, all times mentioned in this paper are local times) in the morning, and reached around $500 \mathrm{~cm}^{-3}$ at noon due to nucleation events at this time (Fig. 4a). However, the median of $N_{3-25}$ did not show similar diurnal variation due to a low NPF frequency. Conversely, both the mean and median of $N_{25-100}$ showed a local maximum during the period from 10:00 to 14:00 (Fig. 4b). NPF events could not have caused this variation, as newly formed particles were not able to grow to $25 \mathrm{~nm}$ in the morning. Therefore, the increase in $25-100 \mathrm{~nm}$ particles originated from primary sources, e.g., traffic sources and biomass burning. Considering that no anthropogenic emission sources exist around the site, those primary particles must have been transported from other regions. Around noontime, when convection is strongest, $N_{25-100}$ can be lifted by the elevated urban PBL, and anthropogenic particles can be injected during this process (Tröstl et al., 2016b). Adak et al. (2014) also reported that the number concentration of $\mathrm{PM}_{1}$ increases during daytime, corresponding to the up-slope valley wind. In the afternoon, the convection become weaker, and the higher wind speed (Fig. 4f) has a stronger scavenging effect on primary particles, meaning that $N_{25-100}$ decreases at around 14:00.

The diurnal change of the absolute water content also supports the fact that the Mt. Yulong site was influenced by an elevated PBL during the midday period. The water concentration was calculated based on temperature and relative humidity, and showed an increase from 3.3 to $4.2 \mathrm{~g} \mathrm{~m}^{-1}$ during the period from 09:00 to 12:00; it then descended back to $3.6 \mathrm{~g} \mathrm{~m}^{-1}$ by $14: 00$ (Fig. 4e). This systematic water content variation indicates that the site was influenced by the 

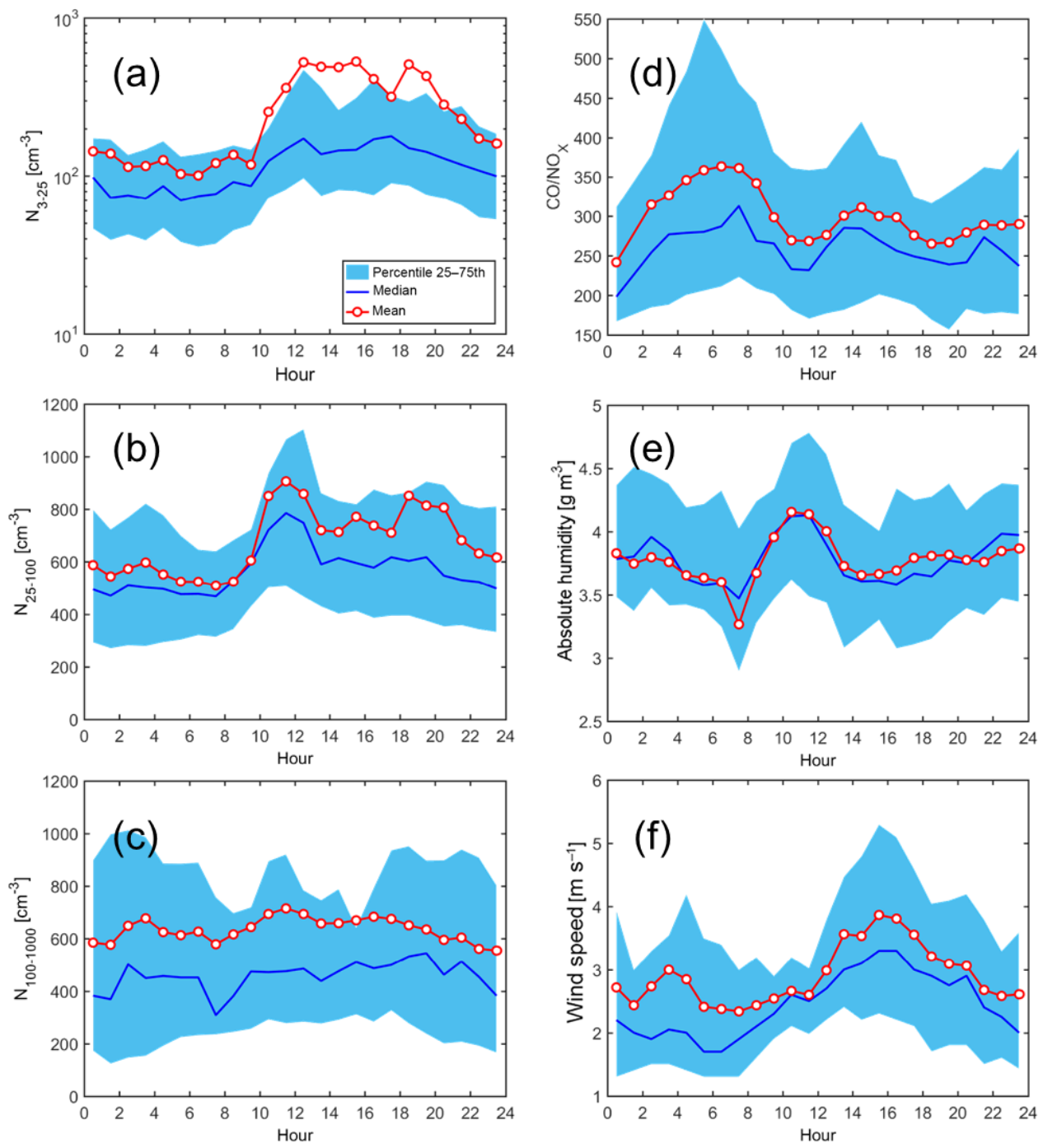

Figure 4. Diurnal variations of $N_{3-25}, N_{25-100}, N_{100-1000}, \mathrm{CO} / \mathrm{NO}_{x}$, wind speed, and absolute humidity at Mt. Yulong during the monitoring campaign. Red lines with circles and blue lines represent the mean and median results, respectively. The light blue area marks the range between the 25 th and 75 th percentiles of the data.

PBL during daytime. Shen et al. (2016) used the increase of the water content in combination with Aitken mode particles to separate the PBL conditions at Mt. Tai. The value of $\mathrm{CO} / \mathrm{NO}_{y}$ and $\mathrm{NO}_{y} / \mathrm{NO}_{x}$ has also been used in other studies to determine the age of air masses arriving at high-altitude sites (Tröstl et al., 2016b; Zellweger et al., 2003; Jaeglé et al., 1998). Because $\mathrm{NO}_{y}$ was not measured in this study, we used $\mathrm{CO} / \mathrm{NO}_{x}$ to estimate the age of air masses since contact with primary emissions. $\mathrm{CO} / \mathrm{NO}_{x}$ was $287 \pm 146$ at Mt. Yulong, which is lower than Jungfraujoch (Herrmann et al., 2015), Mt. Cimone (Cristofanelli et al., 2016), and Kansas (Jaeglé et al., 1998), indicating a stronger anthropogenic influence. The diurnal variation of $\mathrm{CO} / \mathrm{NO}_{x}$ showed a minimum during the period from 09:00 to 14:00 (Fig. 4d), consistent with the local maximum of water content and $N_{25}-100$. The diurnal varia- tion of $\mathrm{O}_{3} / \mathrm{NO}_{x}$ exhibited a similar trend to $\mathrm{CO} / \mathrm{NO}_{x}$, with an average of 69.6 during the period from 10:00 to 14:00, and 83.6 during the period from 01:00 to06:00 (Fig. S2). This evidence indicates that during the period from 10:00 to 14:00 (and quite possibly during the other above mentioned periods), the Mt. Yulong site was influenced by an elevated PBL. In contrast, we consider the data during the 01:00-06:00 period as being the condition within the FT, when $N_{25-100}$ and water content were lowest and $\mathrm{CO} / \mathrm{NO}_{x}$ was highest. However, $N_{100-1000}$ did not show an obvious diurnal variation, indicating that the elevated PBL did not inject large amounts of $100-1000 \mathrm{~nm}$ particles. 

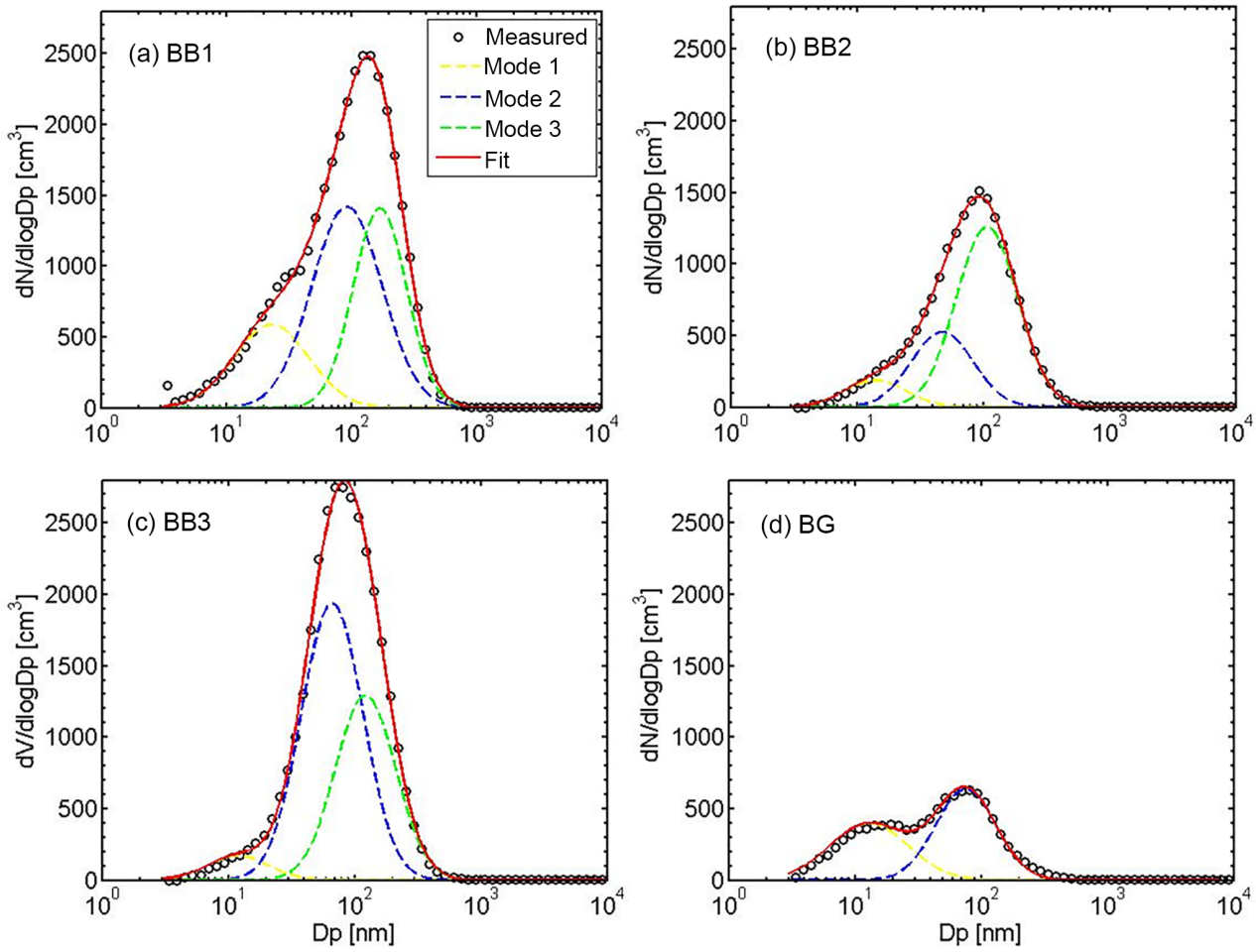

Figure 5. Lognormal fit (three modes) of the average PNSD during (a) BB1, (b) BB2, (c) BB3, and (d) BG at the Mt. Yulong site. Black circles represent the measured PNSD, colored dashed lines represent the PNSD of the fitting modes, and red solid line represents the sum of the PNSD of all fitting modes. Mode 1, 2, and 3 are nucleation mode, Aitken mode, and accumulation mode, respectively.

\subsection{Influences of BB on Mt. Yulong}

\subsubsection{Identification of BB episodes}

The background condition (BG) was chosen to be from 1 to 4 April, when the concentration of $\mathrm{BC}$ was $85 \mathrm{ng} \mathrm{m}^{-3}$ on average. During this period, the wind was relatively strong, and fire spots were barely visible on the westward path of the air mass (Fig. S3). Based on the background condition, three BB events were identified using the following criteria: (1) BC was higher than the background level $\left(85 \mathrm{ng} \mathrm{m}^{-3}\right)$; (2) there was a higher fraction of organic fragment ions with $\mathrm{m} / \mathrm{z}=60$ ( $f 60)$ than during $\mathrm{BG}$ conditions $(0.4 \%)$; and (3) fire spots appeared in the source regions of the air masses or in the areas surrounding the study site.

During the first BB event (BB1, 22 to 30 March), dense fire spots were found in the source region in northern Burma. The $\mathrm{BC}$ concentration $\left(1.2 \mu \mathrm{g} \mathrm{m}^{-3}\right), \mathrm{PV}$, and $f 60$ signal displayed their highest values during BB1. The trajectories of BB2 (5 to 6 April) passed fewer fire spots in southern Asia than those of $\mathrm{BB} 1$, and the $\mathrm{BC}$ concentration was also lower $\left(0.3 \mu \mathrm{g} \mathrm{m}^{-3}\right)$. The concentration of organic components during $\mathrm{BB} 2$ was 4 times higher than the background period. According to an AMS study from the same campaign, organic particles during BB2 were mainly influenced by transported oxidized organics that originated from biomass burning (OOA-BB), as opposed to fresh BB organic aerosols (Zheng et al., 2017). The proportion of $f 60$ was highest $(1.4 \%)$ during BB3 (11 to 12 April), showing a strong BB influence. However, few fire spots were observed along the path of the air mass, indicating that BB particles could have been derived from nearby domestic heating. The study from Zheng (2017) also indicated that organic aerosols showed characteristics closer to those of fresh BBOA compared with BB1.

\subsubsection{Influences of BB on PNSD and CCN}

The average PNSDs during BB events and under BG conditions are plotted in Fig. 5, and fitted by three-mode lognormal distributions. The fitting results are displayed in Table 3. For the BG condition, only two modes were obtained (Fig. 5d), including the nucleation mode (mode_ $1, D_{\text {mean }}=15 \mathrm{~nm}$ ), which originated from nucleation events, and the Aitken mode (mode_2, $D_{\text {mean }}=79 \mathrm{~nm}$ ). The total number concentration of these modes was $669 \mathrm{~cm}^{-3}$, which was similar to the level found at the Swiss Jungfraujoch site (Herrmann et al., 2015); therefore, our study site was found to exhibit a Eurasian background character.

The averaged PNSD during the abovementioned BB episodes showed discrepancies, indicating the variant influences of transported and local BB on particles in atmosphere at Mt. Yulong. During BB2, the Aitken mode number con- 


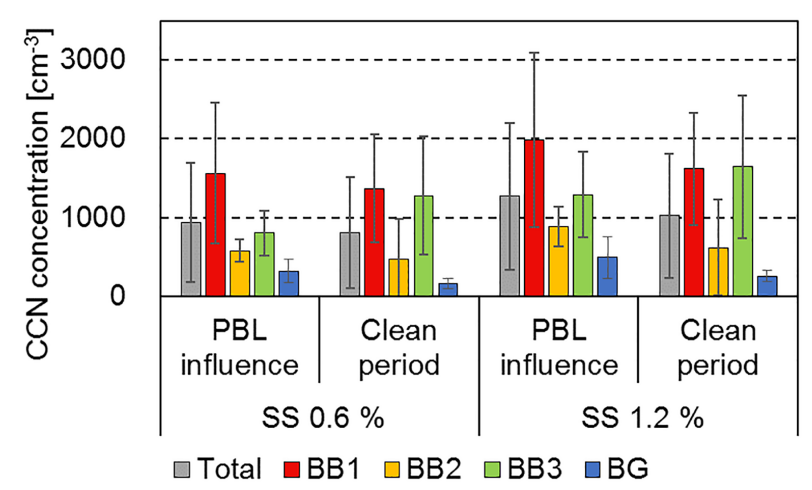

Figure 6. Mean number concentration of $\mathrm{CCN}$ under a supersaturation (SS) of $0.6 \%$ and $1.2 \%$ during the whole monitoring period (labeled as "total") and during the BB1, BB2, and BB3 events (marked as previously described in Fig. 1). PBL (10:00-14:00) and FT (01:00-06:00) conditions were separated.

centration was similar to that of the BG condition. However, an accumulation mode (mode $3, D_{\text {mean }}=106 \mathrm{~nm}$ ) with a higher PN (775 $\mathrm{cm}^{-3}$ ) appeared (Fig. 5b). This mode (with a larger particle size) could be aged particles transported from $\mathrm{BB}$ source regions in southern Asia. In comparison to BB2, Aitken mode particles increased by a factor of 3 and became dominant in the PNSD during BB3 - the local event (Fig. 5c). The number concentration of this mode was $1309 \mathrm{~cm}^{-3}$, 2 times higher than the number concentration of accumulation mode particles. The reason for this could have been that the particles during BB3 were freshly emitted from sources near the monitoring site. The study from Zheng et al. (2017) also showed that the OOA fraction in organic aerosols was relatively lower during this period, while the biomass burning organic aerosol (BBOA) fraction was higher, which indicated impacts from more local BB sources. The geometric mean diameters of the accumulation mode were 169, 106, and $130 \mathrm{~nm}$ during BB1, BB2, and BB3, which was smaller than that of aged biomass burning particles at Mt. Bachelor, USA (Laing et al., 2016); this indicates the particles at Mt. Yulong were fresher. The nucleation mode had lower PN during BB2 and BB3, as the higher number of larger particles acted as strong coagulation sink for nucleation mode particles. The Aitken mode and accumulation mode were comparable during BB1 (Fig. 5a), indicating that the fresh aerosols from sources surrounding the site had a comparable influence to the transported, aged BB aerosols.

In short, the BG condition at Mt. Yulong could represent the background level of particles on the Tibetan Plateau or even for Eurasia. The local and long-range transported BB emissions increase the level of Aitken mode and accumulation mode particles in this region, respectively.

The concentration of $\mathrm{CCN}$ was calculated following the method described in Sect. 2.3.3. The $\kappa$ value during the sampling period was $0.12 \pm 0.01$, which is only one-third of the value found in urban Beijing (Wu et al., 2016) and at a rural site in Thuringia, Germany (Wu et al., 2013); however, this value is consistent with values observed in Alberta, Canada $(0.11 \pm 0.04)$ during BB events (Lathem et al., 2013). Pierce et al. (2012) reported that $\kappa$ was around 0.1 for $>100 \mathrm{~nm}$ particles in a forest mountain valley during biogenic secondary organic aerosol formation and growth events. Similarly, the organic volume fraction was 0.73 in particles at Mt. Yulong, explaining the low value of $\kappa$. As a result, the $D_{\mathrm{c}}$ at supersaturation levels of $0.6 \%$ and $1.2 \%$ was $72.0 \pm 2.2$ and $45.4 \pm 1.4 \mathrm{~nm}$, respectively. There could be uncertainties regarding the values of $\kappa$ and $D_{\mathrm{c}}$, as we used a manually set hygroscopicity of organics, which may have varied with the oxidation level or with other factors (Wu et al., 2016). Considering that the variation in the range of $D_{\mathrm{c}}$ was small, the $\mathrm{CCN}$ concentration was mainly controlled by the size distribution of the particle number.

$\mathrm{BB}$ events raised the $\mathrm{CCN}$ level in atmosphere by influencing the PNSD. An increase in the PN was observed during BB events, i.e., $2207 \pm 1388,1214 \pm 638$, and $2062 \pm$ $1112 \mathrm{~cm}^{-3}$ during $\mathrm{BB} 1, \mathrm{BB} 2$, and BB3, respectively. As a consequence, the increased particles acted as $\mathrm{CCN}$ in the atmosphere at Mt. Yulong, resulting in a rapid increase in the $\mathrm{CCN}$ concentration during BB events. Figure 6 shows the mean number concentration of $\mathrm{CCN}$ in periods influenced by the PBL (10:00-14:00, as discussed in Sect. 3.2) and FT conditions (01:00-06:00) during BG and BB events. The mean number concentration of $\mathrm{CCN}$ under a supersaturation level of $0.6 \%$ was $936 \pm 754$ and $807 \pm 705 \mathrm{~cm}^{-3}$ for the respective PBL and the FT periods at Mt. Yulong, which is comparable to a boreal forest station in Finland (Cerully et al., 2011). The concentration of $\mathrm{CCN}$ in periods influenced by the PBL during $\mathrm{BB} 1, \mathrm{BB} 2$, and $\mathrm{BB} 3$ was 5, 2, and 2 times higher than under BG conditions. Promotions of $\mathrm{CCN}$ during BB1, BB2, BB3 were more remarkable for the FT, i.e., 9, 3, and 8 times that of the BG (Fig. 6). This result indicates that the BB particles from southern Asia could have strong influences on the climate parameters. For the data under a supersaturation of $1.2 \%$, the ratios between the $\mathrm{CCN}$ concentration of $\mathrm{BB}$ and that of the BG were less, i.e., 2-4 times less for periods influenced by the PBL, and 2-7 times less for FT conditions. This is due to the fact that the critical diameters under supersaturation values of $0.6 \%$ and $1.2 \%$ were around 72 and $45 \mathrm{~nm}$, respectively. Furthermore, the PN within $45-72 \mathrm{~nm}$ was relatively stable compared to the larger particles, due to the daily input of anthropogenic primary aerosols from urban air masses.

\subsection{New particle formation events}

\subsubsection{NPF events at Mt. Yulong under anthropogenic influences}

Following the method from Tröstl et al. (2016b) and Yli-Juuti et al. (2009) used, we define three NPF events on 29 March, 4 April, and 13 April as follows: 
a. The "type A" event on 29 March comprised the appearance of newly formed particles $(3 \mathrm{~nm}$, the first bin of nano-SMPS) and the continuous growth of those particles, which reached the upper limit of the nucleation mode $(25 \mathrm{~nm})$. This NPF event was within the BB1 period, when the air mass arriving at Mt. Yulong was from the north of Burma. This air mass displayed slow movement before 28 March and transported abundant pollutants to the study area. From 28 March 12:00 to 29 March 06:00, the air mass was from the western upper troposphere (Fig. S4), which cleaned out the preexisting particles built up by BB events. The condensation sink (CS) at Mt. Yulong decreased from 0.006 to $0.002 \mathrm{~s}^{-1}$ on the morning of 29 March. Conversely, the concentration of $\mathrm{SO}_{2}$ was stable (around $0.04 \mathrm{ppb}$ ) before the occurrence of nucleation. The calculated $\mathrm{H}_{2} \mathrm{SO}_{4}$ increased before nucleation, reaching $5 \times 10^{6} \mathrm{~cm}^{-3}$ (Fig. S4). The nucleation rate was $1.43 \mathrm{~cm}^{-3} \mathrm{~s}^{-1}$, which increased nucleation mode particles to around $10^{4} \mathrm{~cm}^{-3}$. Benefited by the increase of $\alpha$-pinene (from 0.02 to $0.10 \mathrm{ppb}$ ), $\beta$ pinene (from 0.03 to $0.20 \mathrm{ppb}$ ), and $\mathrm{SO}_{2}$ during the day on $29 \mathrm{March}$, the formation of secondary aerosol continued, and the newly formed particles grew to over $30 \mathrm{~nm}$ before nightfall. This process may have been due to gaseous oxidation and condensation. Particle growth stopped during night on 29 March, when the gaseous reaction was inhibited by the absence of sunlight. After sunrise on $30 \mathrm{March}$, the particles continued growing and reached $40 \mathrm{~nm}$. The concentration of toluene was lower than $0.1 \mathrm{ppb}$, which indicated a small contribution from anthropogenic volatile organic compounds (VOCs). The GR was $3.48 \mathrm{~nm} \mathrm{~h}^{-1}$ within the $3-25 \mathrm{~nm}$ size range. In short, under the influence of transported pollutants, nucleation was triggered by the upper clean air mass, which reduced the level of preexisting particles. Furthermore, the growth of particles was favored by the photochemical reaction and condensation process.

b. The "type B" event on 4 April involved a newly formed mode that occurred with a growing trend, but growth stopped at early stage $(<15 \mathrm{~nm})$. There were also temporal low values of $N_{3-25}$ during the event. The event on 4 April took place under $\mathrm{BG}$ conditions, during which the concentration of $\mathrm{SO}_{2}$ was lower (around 0.02 ppb). Beginning at 02:00 on 4 April, the air mass that arrived at Mt. Yulong was transported by an upslope flow from the western lower troposphere. However, from 09:00 to 12:00, the air mass that arrived at Mt. Yulong passed northeastern India where fire spots had been observed on the MODIS map on 2 April. Thus, the gaseous pollutants and particles from nearby anthropogenic sources or from BB sources in northeastern India were transported to this site on morning of
4 April. The concentration of $\mathrm{SO}_{2}$ and $\mathrm{H}_{2} \mathrm{SO}_{4}$ increased to $0.07 \mathrm{ppb}$ and $6 \times 10^{6} \mathrm{~cm}^{-3}$ at $11: 00$, respectively, corresponding to the occurrence of nucleation (Fig. S5). $\mathrm{SO}_{2}$ shared a similar time series to black carbon, indicating a combustion source. The formation rate and growth rate were $0.93 \mathrm{~cm}^{-3} \mathrm{~s}^{-1}$ and $3.2 \mathrm{~nm} \mathrm{~h}^{-1}$, respectively. $N_{3-25}$ fluctuated during the NPF events, showing low values when there were temporary changes in cloud condition (influencing radiation) and wind direction. The concentrations of $\beta$-pinene and toluene were stable and lower than 0.10 and $0.65 \mathrm{ppb}$, respectively, throughout the NPF event, which may have been the reason for the smaller growth rate. At around 14:00, the source region of the air mass changed to the western upper troposphere, and stronger winds cleaned out both the nucleation mode particles and the gaseous precursors, terminating the NPF event. In summary, the type B event was triggered by the injection of gaseous pollutants from an elevated PBL and the short-term transport of BB pollutants under background condition.

c. An "off-site" NPF event occurred on 13 April, during which a narrow particle size distribution band (8$50 \mathrm{~nm}$ ) was observed from 13 to 14 April. Primary particles should have wider range and larger size. These particles were mostly likely nucleated off-site, and transported to Mt. Yulong by an uplifting air mass. On the afternoon of 13 April, the air mass arrived at Mt. Yulong, passing the local ground layer (yellow trajectory in Fig. S6). The $\mathrm{SO}_{2}$ increased from 0.06 to $0.13 \mathrm{ppb}$, and toluene reached its highest level at $0.098 \mathrm{ppb}$ (Fig. S6), which indicated an anthropogenic impact. As a result, particles formed from the ground level were transported to the site and a burst of $N_{3-25}$ occurred at around 18:00. $\beta$-pinene also showed a higher value at dawn on 13 April. These nanoparticles showed a growth trend, with a GR of $2.99 \mathrm{~nm} \mathrm{~h}^{-1}$. To summarize, this NPF event resulted in the occurrence of nucleation mode particles that were nucleated off-site in the PBL and transported to the study site.

These new particle formation events had strong influences on the PNSD. Particles showed a unimodal distribution during non-NPF event periods, with a peak diameter of around $125 \mathrm{~nm}$ (Fig. S7). This is mainly due to the impact from aged biomass burning particles. During the NPF events, the PNSD showed a clear bimodal characteristic. The smaller mode originated from nucleation and the growth of nanoparticles. This mode had a higher peak than the larger mode, indicating that NPF significantly contributed to the particle number concentration.

\subsubsection{Limiting factors of NPF events}

The frequency of NPF was $14 \%$ during our measurement. This NPF frequency is clearly lower than in the polluted at- 


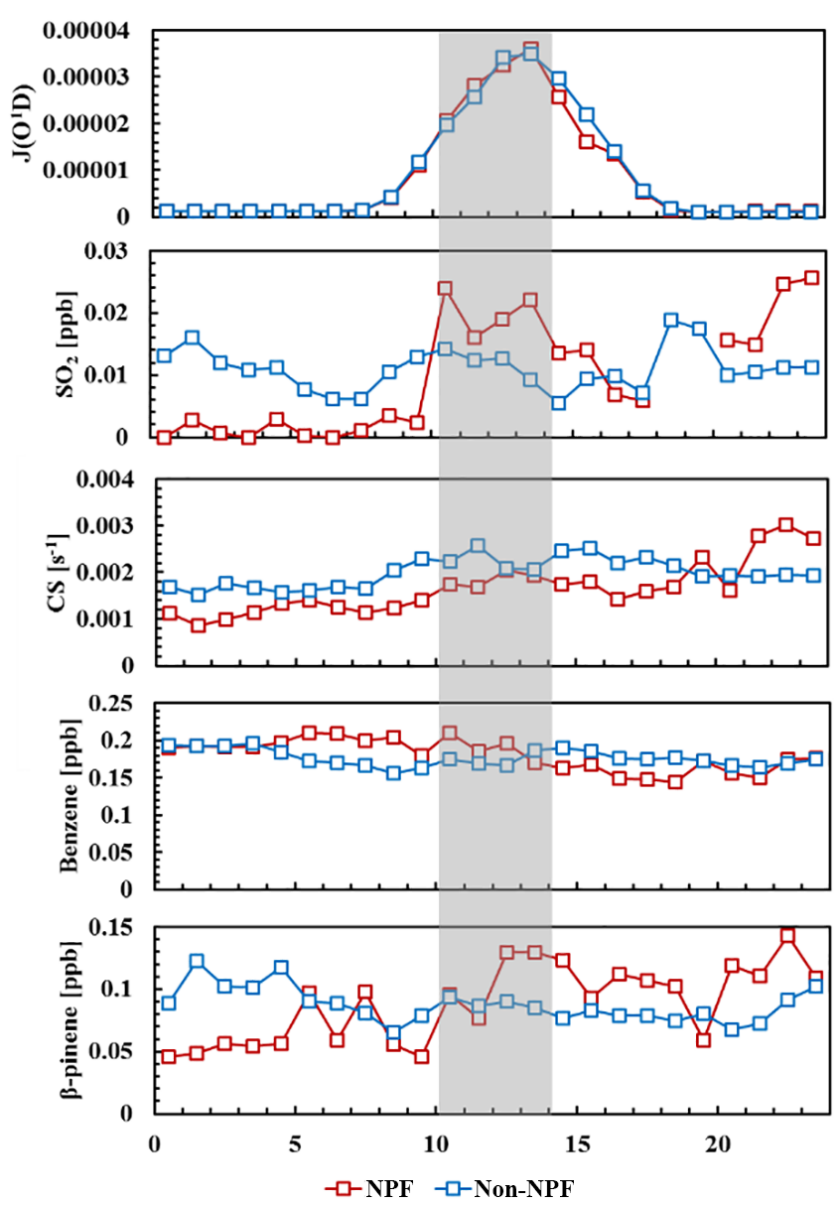

Figure 7. Diurnal variation of $J\left(\mathrm{O}^{1} \mathrm{D}\right), \mathrm{SO}_{2}, \mathrm{CS}$, benzene, and $\beta$ pinene during days with NPF events (labeled as "NPF", red lines), and without NPF events (labeled as "non-NPF", blue lines). The shaded area represents the time period during which nucleation occurred.

mosphere of the North China Plain (40\%-65\%) in March and April (Wang et al., 2013a; Shen et al., 2011), the top of Mt. Huang (38\%) during April (Zhang et al., 2016), a background site on the northeastern Tibetan Plateau (79\%) in autumn (Du et al., 2015), and a remote rural site in the Sierra Nevada Mountains (47\%) in spring (Creamean et al., 2011). It is common knowledge that the CS is the limiting factor that controls NPF (Cai et al., 2017). Thus, preexisting particle levels on event days should be less than non-event days, at high altitude mountain sites (Shen et al., 2016; Guo et al., 2012) and urban sites (Wang et al., 2011, 2017). The low NPF frequency was unexpected in the clean atmosphere of Mt. Yulong, as the mean CS at Mt. Yulong was $0.0038 \mathrm{~s}^{-1}$. Conversely, a similar low frequency of NPF events has also been observed in other locations with pristine atmospheres, e.g., $24 \%$ at the Antarctic site "Neumayer" (Weller et al., 2015 ) and $12 \%-17 \%$ at Dome C, Antarctica (Järvinen et al., 2013).
During the first 5 days of the campaign (22 to 27 March), the nucleation events may have been prevented by large amount of preexisting particles acting as big condensation sink. The CS was more than $0.005 \mathrm{~s}^{-1}$, which was similar to the polluted city of Beijing on days with NPF events (Wu et al., 2007). However, on the remaining days when the CS was even lower than $0.002 \mathrm{~s}^{-1}$, NPF events were still scarce. Considering that the content of condensable vapor that participates in nucleation is determined by competition between formation from precursor oxidation and condensation on surface of preexisting particles (Zhang et al., 2012), the lower NPF frequency at pristine sites could have resulted from a lack of precursors, e.g., VOCs and $\mathrm{SO}_{2}$ from fossil fuel and biomass burning sources.

To further evaluate the effect of different parameters on $\mathrm{NPF}$, the daily variations of $\mathrm{SO}_{2}, \mathrm{CS}, J\left(\mathrm{O}^{1} \mathrm{D}\right)$, benzene, and $\beta$-pinene during the period from 28 March to 14 April were calculated and are plotted in Fig. 7. The results during the period from 10:00 to 14:00 are compared between NPF days and non-event days, as this time period is pinpointed as being when nucleation occurred. As shown in Fig. 7, NPF days and non-NPF days shared the same level of $J\left(\mathrm{O}^{1} \mathrm{D}\right)$, and there was also a $15 \%$ difference in the CS when nucleation happened, indicating a small influence of solar radiation and preexisting particles on NPF. In addition to this, if we removed the data with biomass burning influences from nonNPF days, the averaged PNSD (Fig. S7) would be similar to the PNSD during NPF days in a larger size range $(>80 \mathrm{~nm})$. Considering that larger particles are the main contributor to the condensation and coagulation sink, we can conclude that the CS is not the decisive factor controlling NPF in the pristine atmosphere of Mt. Yulong.

The concentration of $\mathrm{SO}_{2}$ showed an increase on NPF days, and was $60 \%$ higher than on non-event days, indicating that anthropogenic $\mathrm{SO}_{2}$ is the controlling factor of NPF at Mt. Yulong. Studies at Jungfraujoch (Bianchi et al., 2016; Tröstl et al., 2016b), Izaña (García et al., 2014), and Mukteshwar (Neitola et al., 2011) have also reported that nucleation events in the upper troposphere correspond to an increase of anthropogenic gas pollutants due to an elevated PBL. At Daban Mountain on the northern slope of the Tibetan Plateau, the $\mathrm{PM}_{2.5}$ level was similar to Mt. Yulong, but NPF was observed nearly every day. This may have been caused by the fact that concentration of $\mathrm{SO}_{2}$ was around $2 \mathrm{ppb}$ on average, which was 2 orders of magnitude higher than Mt. Yulong.

Organics may have also been a driving factor of NPF. The concentration of $\beta$-pinene showed a higher value (40\%) in the afternoon on NPF days, while there was little difference (9\%) between NPF days and non-event days with regards to the anthropogenic benzene concentration. Recent studies have found that in addition to sulfuric acid, the highly oxidized multifunctional organics from biogenic VOCs can also take part in nucleation and growth (Huang et al., 2016; Tröstl et al., 2016a): in free troposphere, pure organic nucleation 
Table 4. Comparisons of NPF parameters (FR, GR, CS) with the other studies.

\begin{tabular}{llrrrrrl}
\hline Site & Region & $\begin{array}{r}\text { Altitude } \\
{[\mathrm{m}]}\end{array}$ & $\begin{array}{r}\text { Size } \\
{[\mathrm{nm}]}\end{array}$ & $\begin{array}{r}\text { FR } \\
{\left[\mathrm{cm}^{-3} \mathrm{~s}^{-1}\right]}\end{array}$ & $\begin{array}{r}\text { GR } \\
{\left[\mathrm{nm} \mathrm{h}^{-1}\right]}\end{array}$ & $\begin{array}{r}\text { CS } \\
{\left[\mathrm{s}^{-1}\right]}\end{array}$ & Reference \\
\hline Mt. Yulong & Asia & 3410 & $3-25$ & 1.18 & 3.22 & 0.002 & This research \\
Mukteshwar & Asia & 2180 & $15-20$ & 0.44 & 2.47 & 0.015 & Neitola et al. (2011) \\
Storm Peak Laboratory & North America & 3210 & $9-334$ & 0.39 & 7.5 & 0.001 & Hallar et al. (2011) \\
Mt. Tai & Asia & 1500 & $3-25$ & 4 & 6.1 & 0.02 & Shen et al. (2016) \\
Izaña & Atlantic Ocean & 2400 & $10-25$ & 0.46 & 0.43 & 0.002 & García et al. (2014) \\
Jungfraujoch & Europe & 3580 & $3.2-15$ & 1.8 & 4.0 & - & Tröstl et al. (2016b) \\
Dome C & Antarctica & 3200 & $10-25$ & 0.023 & 2.5 & 0.0002 & Järvinen et al. (2013) \\
\hline
\end{tabular}

without sulfuric acid may even be dominant (Bianchi et al., 2016; Gordon et al., 2016). According to the study from Du et al. (2015), the fraction of oxidized organics in the particle phase have a positive relationship with the particle growth rate, which indicates a contribution from organics to particle growth. Therefore, the increase of biogenic VOCs could benefit nucleation and the growth of nucleation mode particles at Mt. Yulong.

\subsubsection{Parameters of NPF events in this study}

The formation rate, growth rate, and condensation sink of NPF events at Mt. Yulong are summarized in Table 4. Compared with other high mountain measurements, this study reported a higher FR, e.g., 3 times the rate recorded at Storm Peak Laboratory (Hallar et al., 2011). However, the GR at Mt. Yulong was within average levels, which indicates that different precursors were participating in the nucleation and growth processes. Even though $\mathrm{SO}_{2}$ showed a good correlated with nucleation events, the calculated growth rate from condensation of $\mathrm{H}_{2} \mathrm{SO}_{4}$ can only explain $5 \%$ of the measured GR. This result indicates the participation of some other precursors in particle growth at this site, e.g., organics.

\section{Conclusions}

The PNSD, meteorological parameters, trace gases, and particle chemical composition were measured at the Mt. Yulong site ( $3410 \mathrm{~m}$ a.s.1.) in the southeastern corner of the Tibetan Plateau during the pre-monsoon season (22 March to 15 April) of 2015. The PNSD in the background atmosphere of the Tibetan Plateau was characterized. As a background site in southwestern China, the atmosphere of Mt. Yulong exhibited a lower particle level and stronger oxidation capacity than low altitude atmosphere.

PBL convection is an influencing factor of the PNSD, which caused readable diurnal variation of $N_{\text {ait }}$. Diurnal variation of $\mathrm{CO} / \mathrm{NO}_{x}$ and absolute humidity showed that the monitoring site was influenced by the PBL during the period from 10:00 to 14:00, and showed typical FT conditions during the period from 01:00 to 06:00.
Three different types of $\mathrm{BB}$ event periods were identified based on the content of $\mathrm{BC}$, the $f 60$, the air mass backward trajectory, and the fire spot map. The accumulation mode was dominant in transported BB particles from Myanmar, but less aged compared with other Tibetan Plateau sites under the influence of BB. During a local biomass burning episode, the Aitken mode was dominant in the PNSD. The biomass burning from southern Asia had a strong influence on climate parameters, especially for the FT. The concentrations of CCN in the FT at Mt. Yulong during BB events were 3-9 times higher than those seen in the BG period. Due to high fraction of organic compounds, the CCN activity of particles in atmosphere at Mt. Yulong was lower than other high altitude sites and ground level sites.

An unexpectedly low NPF frequency was found in clean atmosphere at Mt. Yulong, due to the low concentration of anthropogenic precursor, i.e., $\mathrm{SO}_{2}$. The occurrence of NPF events was favored by the elevated surface emission of $\mathrm{SO}_{2}$ and BB pollutants that were transported from southern Asia. An off-site NPF event was also observed, during which nanoparticles were formed in the PBL and transported to the site. The condensation of sulfuric acid can only explain $5 \%$ of the GR in on-site NPF events, which indicates that other precursors are participating in particle growth. NPF also does not really contribute to $\mathrm{CCN}$ at this site, as the newly formed particles cannot reach the critical diameter.

Our study provided an important dataset regarding particle physical properties on the Tibetan Plateau. The influences of BB activities in southern Asia and the local area on the PNSD and CCN in the atmosphere of the Tibetan Plateau were highlighted. Different types of NPF in the upper troposphere in southwestern China were characterized, and the role of $\mathrm{SO}_{2}$ was analyzed. The results of our study could be used in regional and global climate modeling, and have the potential to help increase the knowledge of NPF in the upper part of troposphere.

Data availability. The data presented in this article are available from the authors upon request (minhu@pku.edu.cn). 
Supplement. The supplement related to this article is available online at: https://doi.org/10.5194/acp-18-15687-2018-supplement.

Author contributions. DS and MH wrote the paper. JP, SG contributed important scientific thoughts. DS and JZ did main analysis of the dataset. DS, YQ, ZD, ML, JF, JP, YW, SL and SG collected the data in the monitoring campaign. All listed authors took part in scientific discussions about this manuscript.

Competing interests. The authors declare that they have no conflict of interest.

Special issue statement. This article is part of the special issue "Study of ozone, aerosols and radiation over the Tibetan Plateau (SOAR-TP) (ACP/AMT inter-journal SI)". It is not associated with a conference.

Acknowledgements. This study was supported by the National Natural Science Foundation of China (grant no. 91544214, 51636003, 21677002) and the China Ministry of Environmental Protection Special Funds for Scientific Research on Public Welfare (201309016). We thank Jie Li and Zhangyu Qia for help with running the WRF model. We also thank our colleagues from the China National Environmental Monitoring Center and Lijiang Monitoring Station for their support with the field campaign.

Edited by: Yan Yin

Reviewed by: three anonymous referees

\section{References}

Adak, A.: Atmospheric Fine Mode Particulates at Eastern Himalaya, India: Role of Meteorology, Long-Range Transport and Local Anthropogenic Sources, Aerosol Air Qual. Res., 14, 440450, https://doi.org/10.4209/aaqr.2013.03.0090, 2014.

Benajes, J., Garcia, A., Monsalve-Serrano, J., and Boronat, V.: Gaseous emissions and particle size distribution of dual-mode dual-fuel diesel-gasoline concept from low to full load, Appl. Therm. Eng., 120, 138-149, 2017.

Bianchi, F., Tröstl, J., Junninen, H., Frege, C., Henne, S., Hoyle, C. R., Molteni, U., Herrmann, E., Adamov, A., Bukowiecki, N., Chen, X., Duplissy, J., Gysel, M., Hutterli, M., Kangasluoma, J., Kontkanen, J., Kürten, A., Manninen, H. E., Münch, S., Peräkylä, O., Petäjä, T., Rondo, L., Williamson, C., Weingartner, E., Curtius, J., Worsnop, D. R., Kulmala, M., Dommen, J., and Baltensperger, U.: New particle formation in the free troposphere: A question of chemistry and timing, Science, 352, 1109, https://doi.org/10.1126/science.aad5456, 2016.

Bonasoni, P., Laj, P., Marinoni, A., Sprenger, M., Angelini, F., Arduini, J., Bonafè, U., Calzolari, F., Colombo, T., Decesari, S., Di Biagio, C., di Sarra, A. G., Evangelisti, F., Duchi, R., Facchini, MC., Fuzzi, S., Gobbi, G. P., Maione, M., Panday, A., Roccato, F., Sellegri, K., Venzac, H., Verza, GP., Villani, P., Vuillermoz,
E., and Cristofanelli, P.: Atmospheric Brown Clouds in the Himalayas: first two years of continuous observations at the Nepal Climate Observatory-Pyramid (507 m), Atmos. Chem. Phys., 10, 7515-7531, https://doi.org/10.5194/acp-10-7515-2010, 2010.

Boy, M., Karl, T., Turnipseed, A., Mauldin, R. L., Kosciuch, E., Greenberg, J., Rathbone, J., Smith, J., Held, A., Barsanti, K., Wehner, B., Bauer, S., Wiedensohler, A., Bonn, B., Kulmala, M., and Guenther, A.: New particle formation in the Front Range of the Colorado Rocky Mountains, Atmos. Chem. Phys., 8, 15771590, https://doi.org/10.5194/acp-8-1577-2008, 2008.

Bukowiecki, N., Weingartner, E., Gysel, M., Coen, M. C., Zieger, P., Herrmann, E., Steinbacher, M., Gäggeler, H. W., and Baltensperger, U.: A Review of More than 20 Years of Aerosol Observation at the High Altitude Research Station Jungfraujoch, Switzerland (3580 m a.s.1.), Aerosol Air Qual. Res., 16, 764-788, https://doi.org/10.4209/aaqr.2015.05.0305, 2016.

Cai, R., Yang, D., Fu, Y., Wang, X., Li, X., Ma, Y., Hao, J., Zheng, J., and Jiang, J.: Aerosol surface area concentration: a governing factor in new particle formation in Beijing, Atmos. Chem. Phys., 17, 12327-12340, https://doi.org/10.5194/acp-17-123272017, 2017.

Cerully, K. M., Raatikainen, T., Lance, S., Tkacik, D., Tiitta, P., Petäjä, T., Ehn, M., Kulmala, M., Worsnop, D. R., Laaksonen, A., Smith, J. N., and Nenes, A.: Aerosol hygroscopicity and CCN activation kinetics in a boreal forest environment during the 2007 EUCAARI campaign, Atmos. Chem. Phys., 11, 12369-12386, https://doi.org/10.5194/acp-11-12369-2011, 2011.

Chen, Y., Cao, J., Zhao, J., Xu, H., Arimoto, R., Wang, G., Han, Y., Shen, Z., and Li, G.: N-alkanes and polycyclic aromatic hydrocarbons in total suspended particulates from the southeastern Tibetan Plateau: concentrations, seasonal variations, and sources, Sci. Total Environ., 470/471, 9-18, https://doi.org/10.1016/j.scitotenv.2013.09.033, 2014.

Cong, Z., Kang, S., Kawamura, K., Liu, B., Wan, X., Wang, Z., Gao, S., and Fu, P.: Carbonaceous aerosols on the south edge of the Tibetan Plateau: concentrations, seasonality and sources, Atmos. Chem. Phys., 15, 1573-1584, https://doi.org/10.5194/acp15-1573-2015, 2015.

Creamean, J. M., Ault, A. P., Ten Hoeve, J. E., Jacobson, M. Z., Roberts, G. C., and Prather, K. A.: Measurements of aerosol chemistry during new particle formation events at a remote rural mountain site, Environ. Sci. Technol., 45, 8208-8216, https://doi.org/10.1021/es103692f, 2011.

Cristofanelli, P., Landi, T. C., Calzolari, F., Duchi, R., Marinoni, A., Rinaldi, M., and Bonasoni, P.: Summer atmospheric composition over the Mediterranean basin: Investigation on transport processes and pollutant export to the free troposphere by observations at the WMO/GAW Mt. Cimone global station (Italy, 2165 m a.s.1.), Atmospheric Environment, 141, 139-152, https://doi.org/10.1016/j.atmosenv.2016.06.048, 2016.

D’Andrea, S. D., Ng, J. Y., Kodros, J. K., Atwood, S. A., Wheeler, M. J., Macdonald, A. M., Leaitch, W. R., and Pierce, J. R.: Source attribution of aerosol size distributions and model evaluation using Whistler Mountain measurements and GEOSChem-TOMAS simulations, Atmos. Chem. Phys., 16, 383-396, https://doi.org/10.5194/acp-16-383-2016, 2016.

Dal Maso, M., Kulmala, M., Riipinen, I., Wagner, R., Hussein, T., Aalto, P. P., and Lehtinen, K. E. J.: Formation and growth of fresh atmospheric aerosols: eight years of aerosol size distribution data 
from SMEAR II, Hyytiala, Finland, Boreal Environ. Res., 10, 323-336, 2005.

Draxier, R. R. and Hess, G. D.: An overview of the HYSPLIT_4 modelling system for trajectories, dispersion and deposition, Aust. Meteorol. Mag., 47, 295-308, 1998.

Du, W., Sun, Y. L., Xu, Y. S., Jiang, Q., Wang, Q. Q., Yang, W., Wang, F., Bai, Z. P., Zhao, X. D., and Yang, Y. C.: Chemical characterization of submicron aerosol and particle growth events at a national background site (3295 ma.s.1.) on the Tibetan Plateau, Atmos. Chem. Phys., 15, 10811-10824, https://doi.org/10.5194/acp-15-10811-2015, 2015.

Ehhalt, D. H. and Rohrer, F.: Dependence of the $\mathrm{OH}$ concentration on solar UV, J. Geophys. Res.-Atmos., 105, 3565-3571, https://doi.org/10.1029/1999jd901070, 2000.

Fröhlich, R., Cubison, M. J., Slowik, J. G., Bukowiecki, N., Canonaco, F., Croteau, P. L., Gysel, M., Henne, S., Herrmann, E., Jayne, J. T., Steinbacher, M., Worsnop, D. R., Baltensperger, U., and Prévôt, A. S. H.: Fourteen months of on-line measurements of the non-refractory submicron aerosol at the Jungfraujoch (3580 ma.s.1.) - chemical composition, origins and organic aerosol sources, Atmos. Chem. Phys., 15, 11373-11398, https://doi.org/10.5194/acp-15-11373-2015, 2015.

García, M. I., Rodríguez, S., González, Y., and García, R. D.: Climatology of new particle formation at Izaña mountain GAW observatory in the subtropical North Atlantic, Atmos. Chem. Phys., 14, 3865-3881, https://doi.org/10.5194/acp-14-3865-2014, 2014.

Gautam, R., Hsu, N. C., Lau, K. M., Tsay, S. C., and Kafatos, M.: Enhanced pre-monsoon warming over the Himalayan-Gangetic region from 1979 to 2007, Geophys. Res. Lett., 36, L07704, https://doi.org/10.1029/2009g1037641, 2009.

Gordon, H., Sengupta, K., Rap, A., Duplissy, J., Frege, C., Williamson, C., Heinritzi, M., Simon, M., Yan, C., Almeida, J., Trostl, J., Nieminen, T., Ortega, I. K., Wagner, R., Dunne, E. M., Adamov, A., Amorim, A., Bernhammer, A. K., Bianchi, F., Breitenlechner, M., Brilke, S., Chen, X. M., Craven, J. S., Dias, A., Ehrhart, S., Fischer, L., Flagan, R. C., Franchin, A., Fuchs, C., Guida, R., Hakala, J., Hoyle, C. R., Jokinen, T., Junninen, H., Kangasluoma, J., Kim, J., Kirkby, J., Krapf, M., Kurten, A., Laaksonen, A., Lehtipalo, K., Makhmutov, V., Mathot, S., Molteni, U., Monks, S. A., Onnela, A., Perakyla, O., Piel, F., Petaja, T., Praplanh, A. P., Pringle, K. J., Richards, N. A. D., Rissanen, M. P., Rondo, L., Sarnela, N., Schobesberger, S., Scott, C. E., Seinfeldo, J. H., Sharma, S., Sipila, M., Steiner, G., Stozhkov, Y., Stratmann, F., Tome, A., Virtanen, A., Vogel, A. L., Wagner, A. C., Wagner, P. E., Weingartner, E., Wimmer, D., Winkler, P. M., Ye, P. L., Zhang, X., Hansel, A., Dommen, J., Donahue, N. M., Worsnop, D. R., Baltensperger, U., Kulmala, M., Curtius, J., and Carslaw, K. S.: Reduced anthropogenic aerosol radiative forcing caused by biogenic new particle formation, P. Natl. Acad. Sci. USA, 113, 12053-12058, https://doi.org/10.1073/pnas.1602360113, 2016.

Guo, H., Wang, D. W., Cheung, K., Ling, Z. H., Chan, C. K., and Yao, X. H.: Observation of aerosol size distribution and new particle formation at a mountain site in subtropical Hong Kong, Atmos. Chem. Phys., 12, 9923-9939, https://doi.org/10.5194/acp12-9923-2012, 2012.

Guo, S., Hu, M., Zamora, M. L., Peng, J., Shang, D., Zheng, J., Du, Z., Wu, Z., Shao, M., Zeng, L., Molina, M. J., and Zhang, R.: Elucidating severe urban haze formation in China, P. Natl. Acad. Sci. USA, 111, 17373-17378, https://doi.org/10.1073/pnas.1419604111, 2014.

Gysel, M., Crosier, J., Topping, D. O., Whitehead, J. D., Bower, K. N., Cubison, M. J., Williams, P. I., Flynn, M. J., McFiggans, G. B., and Coe, H.: Closure study between chemical composition and hygroscopic growth of aerosol particles during TORCH2, Atmos. Chem. Phys., 7, 6131-6144, https://doi.org/10.5194/acp7-6131-2007, 2007.

Hallar, A. G., Lowenthal, D. H., Chirokova, G., Borys, R. D., and Wiedinmyer, C.: Persistent daily new particle formation at a mountain-top location, Atmos. Environ., 45, 4111-4115, https://doi.org/10.1016/j.atmosenv.2011.04.044, 2011.

Harris, S. J., and Maricq, M. M.: Signature size distributions for diesel and gasoline engine exhaust particulate matter, J. Aerosol Sci., 32, 749-764, https://doi.org/10.1016/s00218502(00)00111-7, 2001.

Herrmann, E., Weingartner, E., Henne, S., Vuilleumier, L., Bukowiecki, N., Steinbacher, M., Conen, F., Collaud Coen, M., Hammer, E., Jurányi, Z., Baltensperger, U., and Gysel, M.: Analysis of long-term aerosol size distribution data from Jungfraujoch with emphasis on free tropospheric conditions, cloud influence, and air mass transport, J. Geophys. Res.-Atmos., 120, 9459-9480, https://doi.org/10.1002/2015jd023660, 2015.

Huang, X., Zhou, L., Ding, A., Qi, X., Nie, W., Wang, M., Chi, X., Petäjä, T., Kerminen, V. M., Roldin, P., Rusanen, A., Kulmala, M., and Boy, M.: Comprehensive modelling study on observed new particle formation at the SORPES station in Nanjing, China, Atmos. Chem. Phys., 16, 2477-2492, https://doi.org/10.5194/acp-16-2477-2016, 2016.

Hussein, T., Dal Maso, M., Petaja, T., Koponen, I. K., Paatero, P., Aalto, P. P., Hameri, K., and Kulmala, M.: Evaluation of an automatic algorithm for fitting the particle number size distributions, Boreal Environ. Res., 10, 337-355, 2005.

Järvinen, E., Virkkula, A., Nieminen, T., Aalto, P. P., Asmi, E., Lanconelli, C., Busetto, M., Lupi, A., Schioppo, R., Vitale, V., Mazzola, M., Petäjä, T., Kerminen, V. M., and Kulmala, M.: Seasonal cycle and modal structure of particle number size distribution at Dome C, Antarctica, Atmos. Chem. Phys., 13, 7473-7487, https://doi.org/10.5194/acp-13-7473-2013, 2013.

Jaeglé, L., Jacob, D. J., Wang, Y., Weinheimer, A. J., Ridley, B. A., Campos, T. L., Sachse, G. W., and Hagen, D. E.: Sources and chemistry of $\mathrm{NO}_{x}$ in the upper troposphere over the United States, Geophys. Res. Lett., 25, 1705-1708, https://doi.org/10.1029/97gl03591, 1998.

Kittelson, D. B., Watts, W. F., and Johnson, J. P.: On-road and laboratory evaluation of combustion aerosols - Part 1: Summary of diesel engine results, J. Aerosol Sci., 37, 913-930, https://doi.org/10.1016/j.jaerosci.2005.08.005, 2006.

Kivekäs, N., Sun, J., Zhan, M., Kerminen, V. M., Hyvärinen, A., Komppula, M., Viisanen, Y., Hong, N., Zhang, Y., Kulmala, M., Zhang, X. C., Deli, G., and Lihavainen, H.: Long term particle size distribution measurements at Mount Waliguan, a highaltitude site in inland China, Atmos. Chem. Phys., 9, 5461-5474, https://doi.org/10.5194/acp-9-5461-2009, 2009.

Komppula, M., Lihavainen, H., Hyvärinen, A. P., Kerminen, V. M., Panwar, T. S., Sharma, V. P., and Viisanen, Y.: Physical properties of aerosol particles at a Himalayan background site in India, J. Geophys. Res., 114, D12202, https://doi.org/10.1029/2008jd011007, 2009. 
Kulmala, M., Dal Maso, M., Makela, J. M., Pirjola, L., Vakeva, M., Aalto, P., Miikkulainen, P., Hameri, K., and O'Dowd, C. D.: On the formation, growth and composition of nucleation mode particles, Tellus Ser. B, 53, 479-490, https://doi.org/10.3402/tellusb.v53i4.16622, 2001.

Laing, J. R., Jaffe, D. A., and Hee, J. R.: Physical and optical properties of aged biomass burning aerosol from wildfires in Siberia and the Western USA at the Mt. Bachelor Observatory, Atmos. Chem. Phys., 16, 15185-15197, https://doi.org/10.5194/acp-1615185-2016, 2016.

Lathem, T. L., Beyersdorf, A. J., Thornhill, K. L., Winstead, E. L., Cubison, M. J., Hecobian, A., Jimenez, J. L., Weber, R. J., Anderson, B. E., and Nenes, A.: Analysis of CCN activity of Arctic aerosol and Canadian biomass burning during summer 2008, Atmos. Chem. Phys., 13, 2735-2756, https://doi.org/10.5194/acp13-2735-2013, 2013.

Lunden, M. M., Black, D. R., McKay, M., Revzan, K. L., Goldstein, A. H., and Brown, N. J.: Characteristics of Fine Particle Growth Events Observed Above a Forested Ecosystem in the Sierra Nevada Mountains of California, Aerosol Sci. Technol., 40, 373-388, https://doi.org/10.1080/02786820600631896, 2006.

Lüthi, Z. L., Škerlak, B., Kim, S. W., Lauer, A., Mues, A., Rupakheti, M., and Kang, S.: Atmospheric brown clouds reach the Tibetan Plateau by crossing the Himalayas, Atmos. Chem. Phys., 15, 6007-6021, https://doi.org/10.5194/acp-156007-2015, 2015.

Merikanto, J., Spracklen, D. V., Mann, G. W., Pickering, S. J., and Carslaw, K. S.: Impact of nucleation on global CCN, Atmos. Chem. Phys., 9, 8601-8616, https://doi.org/10.5194/acp-9-86012009, 2009.

Neitola, K., Asmi, E., Komppula, M., Hyvärinen, A. P., Raatikainen, T., Panwar, T. S., Sharma, V. P., and Lihavainen, H.: New particle formation infrequently observed in $\mathrm{Hi}^{-}$ malayan foothills - why?, Atmos. Chem. Phys., 11, 8447-8458, https://doi.org/10.5194/acp-11-8447-2011, 2011.

Nishita, C., Osada, K., Kido, M., Matsunaga, K., and Iwasaka, Y.: Nucleation mode particles in upslope valley winds at Mount Norikura, Japan: Implications for the vertical extent of new particle formation events in the lower troposphere, J. Geophys. Res., 113, D06202, https://doi.org/10.1029/2007jd009302, 2008.

Okamoto, S. and Tanimoto, H.: A review of atmospheric chemistry observations at mountain sites, Prog. Earth Planet. Sci., 3, https://doi.org/10.1186/s40645-016-0109-2, 2016.

Peng, J. F., Hu, M., Wang, Z. B., Huang, X. F., Kumar, P., Wu, Z. J., Guo, S., Yue, D. L., Shang, D. J., Zheng, Z., and He, L. Y.: Submicron aerosols at thirteen diversified sites in China: size distribution, new particle formation and corresponding contribution to cloud condensation nuclei production, Atmos. Chem. Phys., 14, 10249-10265, https://doi.org/10.5194/acp-14-102492014, 2014.

Petters, M. D. and Kreidenweis, S. M.: A single parameter representation of hygroscopic growth and cloud condensation nucleus activity, Atmos. Chem. Phys., 7, 1961-1971, https://doi.org/10.5194/acp-7-1961-2007, 2007.

Pierce, J. R., Leaitch, W. R., Liggio, J., Westervelt, D. M., Wainwright, C. D., Abbatt, J. P. D., Ahlm, L., Al-Basheer, W., Cziczo, D. J., Hayden, K. L., Lee, A. K. Y., Li, S. M., Russell, L. M., Sjostedt, S. J., Strawbridge, K. B., Travis, M.,
Vlasenko, A., Wentzell, J. J. B., Wiebe, H. A., Wong, J. P. S., and Macdonald, A. M.: Nucleation and condensational growth to CCN sizes during a sustained pristine biogenic SOA event in a forested mountain valley, Atmos. Chem. Phys., 12, 3147-3163, https://doi.org/10.5194/acp-12-3147-2012, 2012.

Rodríguez, S., González, Y., Cuevas, E., Ramos, R., Romero, P. M., Abreu-Afonso, J., and Redondas, A.: Atmospheric nanoparticle observations in the low free troposphere during upward orographic flows at Izaña Mountain Observatory, Atmos. Chem. Phys., 9, 6319-6335, https://doi.org/10.5194/acp-9-6319-2009, 2009.

Rose, C., Sellegri, K., Freney, E., Dupuy, R., Colomb, A., Pichon, J. M., Ribeiro, M., Bourianne, T., Burnet, F., and Schwarzenboeck, A.: Airborne measurements of new particle formation in the free troposphere above the Mediterranean Sea during the HYMEX campaign, Atmos. Chem. Phys., 15, 10203-10218, https://doi.org/10.5194/acp-15-10203-2015, 2015.

Shen, X., Sun, J., Zhang, X., Kivekäs, N., Zhang, Y., Wang, T., Zhang, X., Yang, Y., Wang, D., Zhao, Y., and Qin, D.: Particle Climatology in Central East China Retrieved from Measurements in Planetary Boundary Layer and in Free Troposphere at a 1500-m-High Mountaintop Site, Aerosol Air Qual. Res., 16, 659-701, https://doi.org/10.4209/aaqr.2015.02.0070, 2016.

Shen, X. J., Sun, J. Y., Zhang, Y. M., Wehner, B., Nowak, A., Tuch, T., Zhang, X. C., Wang, T. T., Zhou, H. G., Zhang, X. L., Dong, F., Birmili, W., and Wiedensohler, A.: First long-term study of particle number size distributions and new particle formation events of regional aerosol in the North China Plain, Atmos. Chem. Phys., 11, 1565-1580, https://doi.org/10.5194/acp11-1565-2011, 2011.

Sipilä, M., Berndt, T., Petäjä, T., Brus, D., Vanhanen, J., Stratmann, F., Patokoski, J., Mauldin, R. L., Hyvärinen, A.P., Lihavainen, H., and Kulmala, M.: The Role of Sulfuric Acid in Atmospheric Nucleation, Science, 327, 1243-1246, https://doi.org/10.1126/science.1180315, 2010.

Tan, P. Q., Li, Y., Hu, Z. Y., and Lou, D. M.: Investigation of nitrogen oxides, particle number, and size distribution on a light-duty diesel car with B10 and G10 fuels, Fuel, 197, 373-387, 2017.

Tröstl, J., Chuang, W. K., Gordon, H., Heinritzi, M., Yan, C., Molteni, U., Ahlm, L., Frege, C., Bianchi, F., Wagner, R., Simon, M., Lehtipalo, K., Williamson, C., Craven, J. S., Duplissy, J., Adamov, A., Almeida, J., Bernhammer, A.-K., Breitenlechner, M., Brilke, S., Dias, A., Ehrhart, S., Flagan, R. C., Franchin, A., Fuchs, C., Guida, R., Gysel, M., Hansel, A., Hoyle, C. R., Jokinen, T., Junninen, H., Kangasluoma, J., Keskinen, H., Kim, J., Krapf, M., Kürten, A., Laaksonen, A., Lawler, M., Leiminger, M., Mathot, S., Möhler, O., Nieminen, T., Onnela, A., Petäjä, T., Piel, F. M., Miettinen, P., Rissanen, M. P., Rondo, L., Sarnela, N., Schobesberger, S., Sengupta, K., Sipilä, M., Smith, J. N., Steiner, G., Tomè, A., Virtanen, A., Wagner, A. C., Weingartner, E., Wimmer, D., Winkler, P. M., Ye, P., Carslaw, K. S., Curtius, J., Dommen, J., Kirkby, J., Kulmala, M., Riipinen, I., Worsnop, D. R., Donahue, N. M., and Baltensperger, U.: The role of low-volatility organic compounds in initial particle growth in the atmosphere, Nature, 533, 527-531, https://doi.org/10.1038/nature18271, 2016a.

Tröstl, J., Herrmann, E., Frege, C., Bianchi, F., Molteni, U., Bukowiecki, N., Hoyle, C. R., Steinbacher, M., Weingartner, E., Dommen, J., Gysel, M., and Baltensperger, U.: Contri- 
bution of new particle formation to the total aerosol concentration at the high-altitude site Jungfraujoch ( $3580 \mathrm{~m}$ a.s.l., Switzerland), J. Geophys. Res.-Atmos., 121, 11692-11711, https://doi.org/10.1002/2015jd024637, 2016b.

Vu, T. V., Delgado-Saborit, J. M., and Harrison, R. M.: Review: Particle number size distributions from seven major sources and implications for source apportionment studies, Atmos. Environ., 122, 114-132, 2015.

Wang, Z., Wu, Z., Yue, D., Shang, D., Guo, S., Sun, J., Ding, A., Wang, L., Jiang, J., Guo, H., Gao, J., Cheung, H. C., Morawska, L., Keywood, M., and Hu, M.: New particle formation in China: Current knowledge and further directions, Sci. Total Environ., 577, 258-266, https://doi.org/10.1016/j.scitotenv.2016.10.177, 2017.

Wang, Z. B., Hu, M., Yue, D. L., Zheng, J., Zhang, R. Y., Wiedensohler, A., Wu, Z. J., Nieminen, T., and Boy, M.: Evaluation on the role of sulfuric acid in the mechanisms of new particle formation for Beijing case, Atmos. Chem. Phys., 11, 12663-12671, https://doi.org/10.5194/acp-11-12663-2011, 2011.

Wang, Z. B., Hu, M., Sun, J. Y., Wu, Z. J., Yue, D. L., Shen, X. J., Zhang, Y. M., Pei, X. Y., Cheng, Y. F., and Wiedensohler, A.: Characteristics of regional new particle formation in urban and regional background environments in the North China Plain, Atmos. Chem. Phys., 13, 12495-12506, https://doi.org/10.5194/acp-13-12495-2013, 2013 a.

Wang, Z. B., Hu, M., Wu, Z. J., Yue, D. L., He, L. Y., Huang, X. F., Liu, X. G., and Wiedensohler, A.: Long-term measurements of particle number size distributions and the relationships with air mass history and source apportionment in the summer of Beijing, Atmos. Chem. Phys., 13, 10159-10170, https://doi.org/10.5194/acp-13-10159-2013, 2013b.

Weller, R., Schmidt, K., Teinilä, K., and Hillamo, R.: Natural new particle formation at the coastal Antarctic site Neumayer, Atmos. Chem. Phys., 15, 11399-11410, https://doi.org/10.5194/acp-1511399-2015, 2015.

Wu, Z., Hu, M., Liu, S., Wehner, B., Bauer, S., Ma ßling, A., Wiedensohler, A., Petäjä, T., Dal Maso, M., and Kulmala, M.: New particle formation in Beijing, China: Statistical analysis of a 1-year data set, J. Geophys. Res., 112, D09209, https://doi.org/10.1029/2006jd007406, 2007.

Wu, Z., Hu, M., Lin, P., Liu, S., Wehner, B., and Wiedensohler, A.: Particle number size distribution in the urban atmosphere of Beijing, China, Atmos. Environ., 42, 7967-7980, https://doi.org/10.1016/j.atmosenv.2008.06.022, 2008.

Wu, Z. J., Poulain, L., Henning, S., Dieckmann, K., Birmili, W., Merkel, M., van Pinxteren, D., Spindler, G., Müller, K., Stratmann, F., Herrmann, H., and Wiedensohler, A.: Relating particle hygroscopicity and $\mathrm{CCN}$ activity to chemical composition during the HCCT-2010 field campaign, Atmos. Chem. Phys., 13, 79837996, https://doi.org/10.5194/acp-13-7983-2013, 2013.

Wu, Z. J., Zheng, J., Shang, D. J., Du, Z. F., Wu, Y. S., Zeng, L. M., Wiedensohler, A., and Hu, M.: Particle hygroscopicity and its link to chemical composition in the urban atmosphere of Beijing, China, during summertime, Atmos. Chem. Phys., 16, 1123 1138, https://doi.org/10.5194/acp-16-1123-2016, 2016.

Xu, J., Wang, Z., Yu, G., Qin, X., Ren, J., and Qin, D.: Characteristics of water soluble ionic species in fine particles from a high altitude site on the northern boundary of Tibetan Plateau: Mixture of mineral dust and anthropogenic aerosol, Atmos. Res., 143, 4356, https://doi.org/10.1016/j.atmosres.2014.01.018, 2014.

Xu, J. Z., Zhang, Q., Wang, Z. B., Yu, G. M., Ge, X. L., and Qin, X.: Chemical composition and size distribution of summertime $\mathrm{PM}_{2.5}$ at a high altitude remote location in the northeast of the Qinghai-Xizang (Tibet) Plateau: insights into aerosol sources and processing in free troposphere, Atmos. Chem. Phys., 15, 5069-5081, https://doi.org/10.5194/acp-15-5069-2015, 2015.

Yli-Juuti, T., Riipinen, I., Aalto, P. P., Nieminen, T., Maenhaut, W., Janssens, I. A., Claeys, M., Salma, I., Ocskay, R., Hoffer, A., Imre, K., and Kulmala, M.: Characteristics of new particle formation events and cluster ions at K-puszta, Hungary, Boreal Environ. Res., 14, 683-698, 2009.

Yu, F. and Hallar, A. G.: Difference in particle formation at a mountaintop location during spring and summer: Implications for the role of sulfuric acid and organics in nucleation, J. Geophys. Res.-Atmos., 119, 12246-12255, https://doi.org/10.1002/2014jd022136, 2014.

Yue, D. L., Hu, M., Zhang, R. Y., Wang, Z. B., Zheng, J., Wu, Z. J., Wiedensohler, A., He, L. Y., Huang, X. F., and Zhu, T.: The roles of sulfuric acid in new particle formation and growth in the mega-city of Beijing, Atmos. Chem. Phys., 10, 4953-4960, https://doi.org/10.5194/acp-10-4953-2010, 2010.

Zellweger, C., Forrer, J., Hofer, P., Nyeki, S., Schwarzenbach, B., Weingartner, E., Ammann, M., and Baltensperger, U.: Partitioning of reactive nitrogen $\left(\mathrm{NO}_{y}\right)$ and dependence on meteorological conditions in the lower free troposphere, Atmos. Chem. Phys., 3, 779-796, https://doi.org/10.5194/acp-3-7792003, 2003.

Zhang, R., Khalizov, A., Wang, L., Hu, M., and Xu, W.: Nucleation and growth of nanoparticles in the atmosphere, Chem. Rev., 112, 1957-2011, https://doi.org/10.1021/cr2001756, 2012.

Zhang, X., Yin, Y., Lin, Z., Han, Y., Hao, J., Yuan, L., Chen, K., Chen, J., Kong, S., Shan, Y., Xiao, H., and Tan, W.: Observation of aerosol number size distribution and new particle formation at a mountainous site in Southeast China, Sci. Total Environ., 575, 309-320, https://doi.org/10.1016/j.scitotenv.2016.09.212, 2016.

Zheng, J., Hu, M., Peng, J., Wu, Z., Kumar, P., Li, M., Wang, Y., and Guo, S.: Spatial distributions and chemical properties of $\mathrm{PM}_{2.5}$ based on 21 field campaigns at 17 sites in China, Chemosphere, 159, 480-487, https://doi.org/10.1016/j.chemosphere.2016.06.032, 2016.

Zheng, J., Hu, M., Du, Z., Shang, D., Gong, Z., Qin, Y., Fang, J., Gu, F., Li, M., Peng, J., Li, J., Zhang, Y., Huang, X., He, L., Wu, Y., and Guo, S.: Influence of biomass burning from South Asia at a high-altitude mountain receptor site in China, Atmos. Chem. Phys., 17, 6853-6864, https://doi.org/10.5194/acp17-6853-2017, 2017. 